Dumanlı, Ş., Köroğlu, Ö. / Journal of Yasar University, 2018, 13/52, 328-342

\title{
Turist Rehberlerinin Stresle Başa Çıkma Tarzları İle Mizah Tarzları Arasındaki İlișkinin Belirlenmesi ${ }^{1}$
}

\section{Determination of the Relationship Between Tourist Guides' Coping Styles With Stress and Humor Styles}

\author{
Şeyma DUMANLI, Türkiye, dumanliseyma@gmail.com \\ Özlem KÖROĞLU, Balıkesir Üniversitesi, Türkiye, ozlemkoroglu_98@yahoo.com
}

\begin{abstract}
Öz: Turizm olgusunun en önemli yapı taşlarından biri olan turist rehberleri, ülkenin turizm imajinın ve ekonomisinin gelişmesinde önemli bir rol oynamaktadırlar. Turist rehberliği mesleğinin farklı kültürlerle tanışma, farkl yerleri gezip görebilme imkânı gibi olumlu özellikleri barındırmasının yanı sıra, düzensiz ve uzun çalışma saatleri, sürekli bir iş olmaması, mesleğe karşı tehditlerin var olması gibi olumsuz özellikleri de bulunmaktadır. Mesleğin olumsuz özellikleri, turist rehberlerinin stres yaşamalarına neden olmaktadır. Bu noktada, turist rehberlerinin stresle başa çlkma tarzlarının belirlenmesi, ayrıca rehberlerin mesleklerini icra ederken en önemli niteliklerinden bir olması gereken mizah tarzlarının belirlenmesi, memnuniyet düzeyi yüksek ve başarılı bir turun gerçekleşmesi açısından önemlidir. Bu çalışmanın amacını turist rehberlerinin stresle başa çıkma tarzları ile mizah tarzları arasındaki iliş̧kinin belirlenmesi oluşturmaktadır. Araștırmanın verileri, 372 turist rehberinden anket tekniğiyle toplamış ve istatistiksel analizler ile değerlendirmeye alınmıștır. Arastırma sonucunda, katılımcıların stresle basa çıkma tarzları ile mizah tarzları arasında orta düzeyde anlamlı bir ilişki olduğu, mizah tarzları ile stresle başa çıma tarzları arasında ise düşük düzeyde anlamlı bir iliş̧ki olduğu saptanmıştır. Bu doğrultuda stresle bașa çıkabilen turist rehberlerinin, bașa çıkamayan turist rehberlerine göre mizah tarzlarını daha fazla kullandıkları görülmektedir. Stresle başa çıma tarzlarını en çok etkileyen faktörün boyun eğici yaklaşım olduğu, mizah tarzlarını en çok etkileyen faktörün ise kendini geliștirici mizah faktörü olduğu saptanmıştır.
\end{abstract}

Anahtar Sözcükler: Stres, Stresle Başa Çıkma Tarzları, Mizah, Mizah Tarzları, Turist Rehberleri.

Abstract: Tourist guides who are the one of the important milestones of tourism concept, play a crucial role to improve tourism image and economy of a country. In addition to having positive features such as meeting different cultures, visiting different places and seeing them, the tourism guidance profession also has negative features such as irregular and long working hours, lack of continuous work and the presence of threats to the profession. These reasons lead to an inevitable stress and pressure on tourist guides. At this point, it is important to determine the way tourist guides deal with stress, as well as to determine the way of humor that should be one of the most important qualities of the guides while carrying out their profession, to realize a high level of satisfaction and a successful tour.The purpose of this study is to determine the relationship between the stress coping styles and humor styles of tourist guides.The data collected from 372 tourist guides and evaluated with statistical analysis. As a result of the research, it was found that there was a moderately significant relationship between participants' styles of coping with stress and humor styles, and a low level of relationship between humor styles and styles of coping with stress. In this respect, it is observed that the tourist guides who can cope with stress use their humor more than the tourist guides who can not cope with it. It has been determined that the most influential factor of stress coping styles is submissive approach, and the factor that most influences humor styles is the self-enhancing humor factor.

Keywords: Stress, Coping Styles with Stress, Humor, Humor Styles, Tourist Guides.

\section{Giriş}

Teknolojinin her geçen gün gelişmesi, bireylerin gelir düzeylerinin artması ve boş zaman aktivitelerine yönelme eğiliminin artması gibi birçok etken turistik faaliyetlere olan talep artışını da beraberinde getirmektedir. Turizme olan talebin artması, turizmi gelir sağlayıcı önemli bir sektör konumuna getirmiştir (Aslan ve Çokal, 2016: 54; Çelik ve Atik, 2016: 510). Turizmin sosyo-ekonomik etkisinin yanı sıra sosyo-kültürel bir faaliyet olması ve beşeri ilişkilere dayalı olması turizmi diğer sektörlerden ayırıcı bir özellik olarak görülmektedir. Bu bağlamda, turistik faaliyetin şüphesiz en önemli olgusu turistlerdir. Tur süresi boyunca da turistlerin en fazla zaman geçirdikleri ve gerçekleştirdikleri turistik faaliyetlerin memnuniyetine en fazla etkisi olan kişinin ise turist rehberi olduğu düşünülmektedir. Turistlerin turistik faaliyetin devamlılı̆̆ını sürdürmesinin turdan duydukları memnuniyet düzeyi ile doğru orantılı olduğu bilinmekte ve turistlerin turlardan mutlu ayrılmaları önem teşkil etmektedir. Bu noktada, bir turun gerçekleşmesi için olmazsa olmaz olan turist rehberlerine önemli bir rol düşmektedir. Rehberlik mesleğinin özellikleri ve rehberin sahip olması gereken nitelikler göz önünde bulundurulduğunda kolay bir meslek olmadığg görülmektedir. Sürekli insanlarla iç içe olmak, sürekli seyahat etmek, birçok vasfa sahip olmak ve düzensiz çalışma saatlerine ayak uydurmak gibi birçok etken strese neden olabilmektedir. Turun sağlıklı bir şekilde sonuçlanması için de rehberlerin özellikle günümüz şartlarında

\footnotetext{
${ }^{1} \mathrm{Bu}$ makale, Şeyma Dumanlı tarafından hazırlanan "Turist Rehberlerinin Stresle Başa Çıkma Tarzları İle Mizah Tarzları Arasındaki İlişkinin Belirlenmesi" başlıklı yüksek lisans tezinden üretilmiştir. Bu tez çalışması, Balıkesir Üniversitesi Rektörlüğü Bilimsel Araştırma Projeleri Birimi tarafından BAP 2017/013 numaralı proje ile desteklenmiştir.
} 
kaçınılmaz olan ve çağın hastalığı olarak nitelendirilen strese karşı başa çıkma stratejileri geliştirebilmeleri önem taşımaktadır. Ayrıca turist rehberlerinin anlatımlarında sıradan düz bir anlatımdan kaçınarak, turistlere bilgileri ilgi çekici, zihinlerinde canlandırıcı ve mizahi bir bakış açısı ile aktarmaları duyulan memnuniyetin artması açısından önem arz etmektedir. Bu noktada mizah kavramı ön plana çıkmaktadır. Mizahın, turist rehberi için sadece anlatıma renk katan, turist rehberinin kendisini ve turistleri eğlendiren yani sadece gülünç durumları içeren bir olgu olmasından ziyade, aynı zamanda stresli durumlarda bir başa çıkma stratejisi olarak da kullanıldığı düşünülmektedir. Bu nedenle, turist rehberlerinin sahip oldukları mizah tarzlarının belirlenmesi, stresle başa çıkmada bir strateji olarak kullanılıp kullanılmadığının ve turist rehberlerinin hangi mizah tarzına sahip olduklarının saptanması önem taşımaktadır. Bu doğrultuda, turist rehberlerinin stresle başa çıkma tarzları ile mizah tarzları arasındaki ilişkinin belirlenmesi amaçlanmaktadır.

\section{Kuramsal Çerçeve}

\subsection{Stresle Başa Çıkma ve Turist Rehberleri}

Stres kavramını ilk kez ortaya atan ve uzun yıllar bu kavram üzerine çalışmış olan Selye (1976) stresi, vücudun herhangi bir farklı duruma karşı gösterdiği özel olmayan yaygın bir tepki şeklinde tanımlamıştır. Bununla birlikte Selye stresi bir algılama olayı olarak tanımlamaktadır. Örneğin; acılı bir darbe ve tutkulu bir öpücük aynı ölçüde stres oluşturabilmektedir. $\mathrm{Bu}$ doğrultuda stres, memnuniyet ya da rahatsızlık duygusu uyandırıp uyandırmadığına bakılmaksızın, tüm durum veya olaylara bedenin ayak uydurmak adına sergilediği genel bir tepki olarak tanımlanmaktadır (Selye, 1976: 137-138). Bununla birlikte stres, bireyin herhangi bir biyolojik ya da fizyolojik uyaran karşısında gerekli olan uyumu yakalayabilmek için bedensel ve ruhsal olarak harekete geçmesi şeklinde de ifade edilmektedir (Sarıkaya, 2007: 2). Bireyler hayatları boyunca güzel ve mutluluk verici olaylarla karşılaşmamaktadırlar. Her ne kadar istenmese de karşı karşıya gelinen olumsuz durumlar/olaylar neticesinde birey hissettiği zorlanma ve sıkıntıyı hafife indirgemek ve sorunu hallederek eski haline dönebilmek için farklı yöntemler denemektedir. Bu doğrultuda stres ve başa çıkma kavramlarından bahsedilmektedir (Yamaç, 2009: 24).

Stresle başa çıkmak, stresin birey üzerinde oluşturduğu etkiyi sürekli olarak olumlu düzeyde tutabilmeyi öğrenmek olarak tanımlanmaktadır (Erdem, 2015: 35). Bunun yanı sıra stresle başa çıkma, bireyin psikolojik ve fizyolojik kaynaklarının zorlanarak tükenmesi durumunda gösterdiği, uyum sağlamaya yönelik davranışsal ve bilişsel çabaların tümüdür (Aldwin, 2007: 31-40). Başa çıkma bireyi stresli durumdan çıkarmaya yönelik, bilişsel yapılanma ve kişisel öğrenmeler yoluyla kullanılmaktadır. Başa çıkma diğer davranışlar gibi durum ve kişilik ilişkisi sürecinin sonucudur. Temel olarak başa çıkma, stres verici olay ya da durum ile kişi arasındaki olağanüstü karşı koyma sürecidir, rahatsızlık verici durumlara karşı belirgin bir mücadele ve değerlendirme çabasıdır (Yurtsever, 2009: 108-109). Stresle başa çıkma, beden ve ruh sağlığını iyi etme, verimli ve üretken bir yaşam sürdürmek açısından gereklidir (Schafer, 1987: 310). Demirüstü vd. (2009) tarafından yapılan çalışmada da stres ile başa çıkabilen bireylerin genel sağlık durumlarının daha iyi olduğu saptanmıştır. Stresin bütününden kurtulmanın olanaksız olduğu düşünülmektedir. Bu nedenle stresle başa çıkmanın amacı enerji, verimlilik ve çevikliğe doğru pozitif bir kuvvet oluşturmaktır. Bu doğrultuda minimum stres seviyesini korumanın önemli olduğu düşünülmektedir (Schafer, 1987: 310).

Stresle başa çıkmada ilk olarak stresin farkına varmak ve bu durumun kişiyi ne yönde etkilediğini bulmak gerekmektedir. $\mathrm{Bu}$ aşamanın sonrasında bireyden bireye değişkenlik gösteren çeşitli başa çıkma stratejileri vardır. Bu noktada, mizah stresle başa çıkmada kullanılan bir kavram olarak ortaya çıkmaktadır. Gülünç ve espri kavramlarından farklı boyutlarıyla da ele alan Freud'a göre mizah, bireyin huzursuz edici durumlarla, istenmeyen duyguların etkisine girmeden, yüzleşmesine yardımcı olan ve rahatsız edici durumlara karşı haz sağlanmasına yardım eden, sağlıklı bir başa çıkma stratejisidir (Freud, 1998: 257-258). Mizah, bireyler tarafından; kişilerarası gerilimi ve çatışmaları azaltmak veya diğer bireylerin yaşadıkları güzel duyguları arttırmak niyetiyle kullanıldığı zaman daha verimli sosyal ilişkilere olanak sağlamaktadır. Bu doğrultuda da mizahın stresin etkilerinin azaltmadaki bir diğer rolünün de bireyin sosyal çevre ağını zenginleştirmesi olduğu görülmektedir. Bunun yanı sıra mizah duygusunun başa çıkma stratejisi olarak değerlendirilmesinin, gülme veya gülmeme aralığından çok, sorun oluşturan durumların eğlenceli tarafını görebilmekle ve stresli durumlarda da mizahi bakış açısını sürdürebilmekle ilişskili olduğu düşünülmektedir (Martin, 2004: 5).

Turist rehberi; kültür elçisi olarak da nitelendirilen, bölgenin tarihi, kültürel ve doğal güzelliklerini en uygun şekilde tanıtan, yorumlayan ve anlatan kişidir (Aslan ve Çolak, 2016: 54). Kültürlerarası bir olay olan turizm faaliyeti, yerel halk ile turisti bir araya getirmekte ve bu şekilde farklı kültürlere sahip olan bireyler arası kültürel etkileşimi olanaklı kılmaktadır. Bu bağlamda, yerel halk ve turist arasında oluşan kültürel boşluğu doldurma görevi de turist rehberlerine düşmektedir (Köroğlu, 2009: 1336). Turist rehberliği mesleği insan gücüne dayanan, bire bir iletişim ve etkileşimin olduğu emek yoğun bir meslektir. Kişilerarası iletişimin etkili ve uygun olması, stres yaşantısı açısından oldukça önemlidir. Bireylerin ilişkilerinin kalitesini belirleyen faktör iletişimdir. Etkili olmayan iletişim sonucunda, kişilerarası ilişkiler, yaygın bir stres kaynağı durumuna gelebilmektedir (İşçen, 2006: 41). Bu doğrultuda kişiler arası ilişkilerin stres kaynağı olmasını önlemek için etkili iletişim kurma becerisinin gelişmesi önemli rol oynamaktadır. Bu becerilerden bazıları; insanları dikkatli dinlemek, beden dilinde iletişime duyarlı olmak, sakin konuşmak ve etkili mesaj yollamak olarak belirtilmektedir (Patel, 1989: 251). Bu bağlamda, turist rehberliği mesleğinin kişilerarası iletişime dayalı olması ve turistler ile turist rehberleri arasındaki iletişimin düzgün kurulması mesleki hayattaki stresin azaltılması açısından önemli olduğu düşünülmektedir. 
Turist rehberliği mesleğinin; sosyallik ve tecrübe kazandırıcı olması, sürekli kendini yenileme zorunluluğunun olması gibi özelliklerinin yanı sıra çalışma saatlerinin belirsiz olması, fiziki efora dayanan bir meslek olması, mevsimsel bir iş olması, iş güvencesinin bulunmaması, dışsal etkenlere dayalı olması (doğal afet, politik durumlar, krizler vb.), emekliliğinin olmaması ya da geç olması gibi özellikleri bulunmaktadır (Güzel, 2007: 34-38). Ayrıca turist rehberlerinin mesleğin zorunlu kıldığı uzun süreli seyahatlere çıkması ve günlerce yaşadığı ortamdan uzak kalması aile ilişkileri üzerinde de önemli ölçüde etkide bulunmaktadır (Doğan ve diğerleri, 2010: 3432). Bu özelikler göz önünde bulundurulduğunda strese neden olabilecek pek çok kaynağın olduğu görülmektedir. Rehberlerin sürekli seyahat halinde olmaları ve bunun beraberinde getirdiği meslek hastalıkları, çalışma saatlerindeki düzensizlik ile hem ruhsal ve fiziksel rahatsızlıklar hem de aile yaşantısında oluşabilecek olumsuz durumlar strese neden olabilmektedir. Bunların yanı sıra pek çok durumdan olumsuz etkilenebilen turizm sektöründe, işsiz kalma tehdidinin var olması ve rehberlik mesleğinin sürekliliğinin olmaması maddi açıdan da stres oluşturabilmektedir. Turlarda yaşanılabilecek olumsuzluklar, turist gruplarıyla yaşanılabilecek sorunlar gibi stres yaratıcı durumlar olabilmektedir. Rehberlerin bu stres verici durumlarla baş edebilmeleri mesleğin icra edilebilmesi, turistlerin sağlıklı ve başarılı bir tur geçirebilmesi ve rehberin fiziksel ve ruhsal sağlı̆̆ı açısından önemli olduğu düşünülmektedir.

Turist rehberi için stres kaynağı olabilecek durumlarda, içinde bulunulan durumu yok etmek mümkün olamayacağ için strese karşı direnç göstermek veya kendine stresle başa çıkma konusunda uygun bir strateji geliştirmek yapılabilecek en mantıklı şeyler arasındadır. Stresle başa çıkmada farklı yöntemler mevcuttur. İlk olarak bedensel ve zihinsel dinginliği sağlamaya yönelik olarak, gevşeme egzersizleri, sporlar, meditasyon (derin düşünme), solunum egzersizleri gibi yöntemler rehberlerin gündelik yaşamda kişisel huzura ermesini; olumsuz durum ve olayları geçici bir evre olarak değerlendirerek, mantıklı çözümler üretebilmesini sağlayacaktır. Bunların yanı sıra, sosyal destek programları, iletişimi güçlendirme, zaman yönetimi, mesleki beceriler kazanma, amaç belirleme programları, rolleri açığa kavuşturarak çatışmayı yönetme gibi uygulamalar, stresle başa çıkma stratejisi olarak kullanılabilecek araçlardan bazılarıdır (Bayram ve Zengin, 2017: 201).

\subsection{Mizah ve Turist Rehberleri}

Mizah, karşılaşılan olayların çelişken, komik ve alışılmamış yönlerini yansıtarak bireyi mevzubahis konular üzerinde eğlendirme, düşündürme veya güldürme sanatı olarak bilinmektedir (Yardımc1, 2010: 2). Bunun yanı sıra mizah, eleştirirken neşelendiren ve bununla birlikte düşünmeyi sağlayan, kıvrak bir zekâ gerektiren gülme durumu olarak da tanımlanmıştır (Bilge, 2008: 7). Mizah duygusu, bireylerin gülünç olan herhangi bir durumu, olayı algılayabilme, görebilme ve anlatabilme becerisi olarak tanımlanmaktadır. Bununla birlikte mizah duygusu bireylerin komik bulduğu durumların türleri, mizahı yaşayışları, anlatışları ve günlük hayatta verdikleri mizah tepkilerinin aralığı gibi kişisel farklılıkların yaşandığı duygu olarak da ifade edilmektedir (Erözkan, 2009: 57; Akyol, 2011: 34).

Bireylerin günlük yaşantılarında mizahla iç içe oldukları düşünülmektedir. Her birey farkında olarak ya da olmayarak bir şekilde mizahı kullanmaktadır. Bu nedenle bireylerin yaptıkları mizahın, kendi kişiliklerinin de etkisiyle ortaya çıkması, mizahın da kendi içinde çeşitlenmesine ve birbirinden ayrılan çeşitli özellikleri içinde barındıran farklı tarzlardan oluşmasına sebep olmaktadır (Özer, 2014: 32). Mizahın birey tarafından kendi kendine katkı sağlamak amacıyla kullanılması, bir savunma mekanizması veya başa çıkma stratejisi olarak kullanımını içermektedir. Bunun yanı sıra bireyin, baskı, tehdit veya sıkıntılı durumlarda kendini yeterli ve güçlü hissettiğini göstermesinin bir yolu olarak kullanımının da kara mizahla ilgili olduğu düşünülmektedir. Mizahın, bireyin diğer bireylerle ilişkisinde katkı sağlamak amacıyla kullanımı ise mizahın diğer bireyleri kendilerinin iyi hissetmesini sağlamak niyetiyle, çatışmaları azaltıcı, bireyin sosyal cazibesini arttırıcı, kişiler arası ilişkileri güçlendirici ve kişiler arası iletişimi kolaylaştırıcı bir şekilde kullanılmasını içermektedir (Karagöz, 2009: 6; Özdemir vd., 2011: 411).

Turist rehberlerinin mesleklerini başarılı bir şekilde icra edebilmeleri için bazı kişisel özelliklere sahip olmaları gerekmektedir. Bunlar; iletişim, liderlik, sabır ve hoşgörü, mizah yeteneği, fiziki görünüş, mesleğe ait teknik ve eğitsel donanımlara sahip olmak, mesleki etik ve kararlı olmak bunların yanı sıra anadiline hâkim olmak, tarihi, aktüel olayları, ziyaret edilen ülke hakkında bilgi sahibi olmak, yöre hakkında bilgili olmak, genel kültür ve ziyaret edilen ülkenin diline vakıf olmak şeklinde belirtilmektedir (Batman vd., 2000: 24-34). Bu doğrultuda, turist rehberlerinin sosyal rolü, gruplara anlatım yaptıkları süre boyunca eğlendirici bir yorum gücüne sahip olmaları, anlatımlarında mizahı da kullanmaları turist grubunda uyumun oluşturulması sürecini oluşturmaları ile ilişkilendirilmektedir (Güzel ve Köroğlu, 2014: 943). Bununla birlikte rehberlerin anlatımlarında mizaha yer vermeleri ya da eğlendirici bir yorum kullanmaları, grup uyumunun sağlanmasında etkin bir araçtır. Mizah veya eğlendirici yorumlar, grup içindeki olumsuz havay1 değiştirerek, grup üyelerinin zorlu doğa koşullarında biraz da olsa eğlenmesini sağlayarak pozitif ortamlar oluşturabilmektedir. Bunun yanı sıra mizah, bireylere, yabancı turistlerin de o gruba ait olduklarını kabul ettirmede aracı olarak kullanılmaktadır. Mizah, turist grubunun tura karşı ilgisini arttırmakta, zevkli ve neşeli bir deneyim yaşanmasına yardımcı olmaktadır (Howard vd., 2001: 34). Turist rehberliği mesleğinde yukarıda da bahsedildiği gibi mizah sahibi olmanın; gruplara yapılan anlatımların daha akılda kalıcı olması, daha eğlenceli ve güzel bir tur deneyiminin yaşanması, anlatılan şeylerin zihinde canlandırılabilmesi, rehber ve turist grubu arasındaki iletişimin güçlenmesi, tek düze sıradan bir anlatımın yerine daha eğlenceli ve akılda yer edici şekilde turun ilerlemesi açısından önem taşıdığı düşünülmektedir. Bu noktada rehberlerin hangi mizah tarzına sahip olduklarının da belirlenmesi oldukça önemlidir. Çünkü olumsuz mizah tarzına sahip rehberler karşılaşılan aksiliklerle olumlu mizah tarzına sahip olan rehberlere göre daha zor baş edebilmektedirler. Rehberlik mesleğinin özellikleri ve zorlukları göz önünde 
bulundurulduğunda, rehberlerin olumlu mizah tarzına sahip olmaları turun gidişatı ve turistlerin memnuniyeti açısından daha verimli olabileceği düşünülmektedir. Mesleğin icrası sırasında yaşanabilecek olumsuz ve stresli durumlarla başa çıkma açısından da rehberlerin mizah anlayışının önemli olduğu varsayılmaktadır. Mizahın, stresle başa çıkmada önemli bir rol oynadığı düşünülmektedir. Örneğin, Özdemir ve diğerleri (2011) tarafından ilkokul öğretmenlerinin mizah tarzları ile stresle başa çıkma tarzları arasındaki ilişkinin ortaya çıkarılması amacıyla yapılan çalışmada, olumlu mizah tarzlarından olan kendini geliştirici ve katılımcı mizah tarzlarını kullanan öğretmenlerin stresle sağlıklı baş etme stratejilerini daha çok kullandıkları saptanmıştır. Abel (2002) tarafından mizah ve stresle başa çıkma tarzlarının birbiriyle ilişkisini belirlemek amacıyla yapılan benzer bir çalışma sonucunda da, öğrencilerin benzer yaşam olaylarıyla karşılaşmış olmalarına rağmen olayları mizah duygusu yüksek olan öğrencilerin, düşük olan öğrencilere kıyasla daha az stresli algıladıkları tespit edilmiştir. Ayrıca bir olayı ya da durumu baştan şekillendirmede mizahın destekleyici bir role sahip olduğunu ve strese yönelik problem merkezli ve duygu merkezli başa çıkma tarzlarının mizahla ilişkili olduğu saptanmıştır. Ayrıca literatürde mizah tarzlarının farklı değişkenlerle ilişkisinin incelendiği çalışmalar da mevcuttur. Örneğin, Overholser (1992) tarafından yapılan çalışmada üniversite öğrencilerinin olumsuz yaşam hadiseleri ile depresyon, benlik saygısı ve yalnızlık arasındaki ilişkilerde mizah duygusunun aracı rol oynayıp oynamadığının belirlenmesi amaçlanmıştır. Araştırma sonucunda, mizah duygusunun yalnızlık ve depresyonla olumsuz yönde, benlik saygısı ile ise olumlu yönde ilişkide oldukları belirtilmiştir. Hampes (2006) tarafından utangaçlık ve mizah tarzları arasındaki ilişkinin belirlenmesi amacıyla bir çalışma yapılmıştır. Araştırma sonucunda, utangaçlık ve kendini yıkıcı mizah tarzları arasında olumlu yönde anlamlı bir ilişki saptanırken, utangaçlık ve katılımcı mizah arasında ise olumsuz yönde bir ilişki olduğu saptanmıştır. Utangaçlık, saldırgan mizah ve kendini geliştirici mizah tarzları arasında ise anlamlı bir ilişkiye rastlanmamıştır. Martin vd. (1993) tarafından yapılan çalışmada ise yüksek mizah duygusuna sahip olan öğrencilerin kendi hayatlarına yönelik daha çok kontrole sahip oldukları ve yüksek özsaygıya sahip oldukları sonucu tespit edilmiştir. Literatürde bu konu ile ilgili yer alan çalışmaların çoğunluğunun öğrenciler üzerinde yoğunlaştığı görülmektedir. Oysa yapılan literatür taraması sonucunda turist rehberlerinin stresle başa çıkma tarzları ile mizah tarzları arasındaki ilişkinin belirlenmesi amacıyla yapılmış bir çalışmaya rastlanmamıştır. Bu durum literatüre katkı sağlaması açısından çalışmanın önemini ortaya koymaktadır.

\section{Yöntem}

T.C. Kültür ve Turizm Bakanlığı web sayfasında bulunan 2018 yılı güncel verileri göz önünde bulundurulduğunda Türkiye'de 10.411 turist rehberi olduğu görülmektedir. Bu rehberlerden çalışma kartına sahip olanların sayısı 7.055 olarak belirtilmektedir (Araştırma ve Eğitim Genel Müdürlüğü, 2018). Bu doğrultuda araştırmanın evrenini çalışma kartına sahip olan 7.055 turist rehberi oluşturmaktadır. Fakat evrenin bütününe ulaşmanın zaman, veri analizi ve maliyet unsurları göz önünde bulundurulduğunda, evreni temsil edebilecek bir örneklem üzerinde çalışmanın yürütülmesinin araştırmacılar için büyük bir avantajdır (Büyüköztürk vd., 2016: 81). Bu nedenle, araştırmada tesadüfi olmayan örnekleme yöntemlerinden kolayda örnekleme metodu seçilmiştir. Bununla birlikte, birincil verilerin toplanması amacıyla en etkili veri toplama aracı olarak düşünülen anket yönteminden faydalanılmıştır (Altunışık vd., 2012: 80). Anket formunun hazırlanmasıyla 2018 yılı Ocak ayından itibaren yaklaşık olarak beş aylık bir zaman diliminde turist rehberlerine anket uygulanmıştır.

Evren büyüklüğü 8.000 olan araştırmalar için kabul görülebilir örneklem sayısı 367 olarak belirtilmektedir (Altunışık vd., 2012: 137). Çalışma kapsamında 376 turist rehberinden geri dönüş sağlanmıştır. Ancak bu anketlerden dört tanesi yetersiz veriye ve anlamlılığa sahip olması sebebiyle değerlendirme dişında bırakılmıştır. Araştırmanın analizleri 372 anket formu üzerinden yürütülmüştür. Araştırma kapsamında elde edilen bu örneklem sayısının evreni temsil etme gücünün yeterli ve yüksek olduğu düşünülmektedir (Altunışık vd., 2012: 137).

Araştırmanın anket formu üç bölümden oluşmaktadır. Oluşturulan formun birinci bölümünü turist rehberlerinin demografik özelliklerini ölçmeye yönelik çoktan seçmeli, iki şıklı ve birden çok seçmeli sekiz soru oluşturmaktadır. Oluşturulan bu soru formunda katılımcıların cinsiyetleri, medeni durumları, yaşları, öğrenim durumları, mesleki rehberlik eğitimlerini nerede aldıkları, yabancı dilleri, mesleği icra etme süreleri, çalışma şekilleri ve bağlı oldukları odalar ile ilgili sorulara yer verilmiştir. Bunun yanı sıra bu bölümde araştırmanın amacını oluşturan stres ve mizah değişkenleri ile ilgili iki şıklı iki soruya da yer verilmiştir. Bu sorularda turist rehberlerinin meslek hayatlarının stresli olup olmadığı ve mesleki hayatta yaşadıkları stresi azaltmak için mizahı kullanıp kullanmadıkları sorulmuştur.

Anket formunun ikinci bölümünde "stresle başa çıkma tarzları ölçeği” yer almaktadır. Bu ölçek Folkman ve Lazarus (1980) tarafından geliştirilen Başa Çıkma Yolları Envanterinden (Ways of Coping Inventory) yola çıkılarak bireylerin stresle başa çıkma tarzlarını ölçmek amacıyla Şahin ve Durak'ın (1995) Türkçeye uyarladığı bir ölçme aracıdır. Orijinal halinde 66 ifadeden oluşan ölçek 4'lü Likert tipi (1. \%0, 2. \%30, 3. \%70 ve 4. \%100) cevaplanması beklenen 30 maddeden oluşan bir forma dönüştürülmüş̧ür. Bu ölçekte beş ayrı alt boyut bulunmaktadır. Bunlar; sosyal destek arama, iyimser, kendine güvenli, boyun eğici ve çaresiz yaklaşım olarak belirtilmektedir. Alt ölçeklerde yer alan madde sayıları şu şekildedir; sosyal destek arama $\left(1^{*}, 9^{*}, 29,30\right)$, iyimser yaklaşım $(2,4,6,12,18)$, kendine güvenli yaklaşım $(8,10,14,16,20,23,26)$, boyun eğici yaklaşım $(5,13,15,17,21,24)$ ve çaresiz yaklaşım $(3,7,11,19,22$, $25,27,28$ ) olarak belirlenmiştir. (* ile işaretlenen maddeler ters çevrilerek puanlanmaktadır).

Anket formunun son bölümünde ise "mizah tarzları ölçeği” (Humor Styles Questionnaire) yer almaktadır. Mizah tarzları ölçeğinin orijinali, Martin ve diğerleri (2003) tarafindan 60 madde olarak geliştirilmiştir. Martin ve diğerleri (2003) tarafından yapılan araştırmada ortaya konulan mizah tarzları; dört ayrı mizah tarzından oluşmaktadır. Bunlardan 
iki tanesi olumlu ve sağlıklı mizah tarzları ve diğer iki tanesi de olumsuz ve sağlıksız mizah tarzları olarak mizahın günlük hayatta kullanımındaki bireysel farklılıklar açısından ele alınmaktadır. Olumlu mizah tarzları; "kendini geliştirici mizah" ve "katılımcı mizah"; olumsuz mizah tarzları ise "kendini yıkıcı mizah" ve "saldırgan mizah" olarak belirtilmektedir (Martin vd., 2003: 53-54). Ölçek Yerlikaya (2003) tarafindan Türkçe’ye çevrilmiş ve 32 maddeye düşürülmüştür. Bu çalışmada Martin ve diğerleri (2003) tarafından geliştirilen mizah tarzları ölçeğinin E. Yerlikaya (2003) tarafindan Türkçe'ye çevirisi yapılan ve 32 maddeye indirgenen hali kullanılmıştır. Ölçeğin derecelendirilmesi 7'li Likert tipindedir. Katılımcılardan ölçekte yer verilen sorulara “1. Kesinlikle Katılmıyorum, 2. Katılmıyorum, 3. Biraz Katılmıyorum, 4. Kararsızım, 5. Biraz Katılıyorum, 6. Katılıyorum, 7. Tamamıla Katılıyorum” cevaplarından birini seçerek yanıtlamaları istenmiştir. Ölçeğin alt boyutlarının maddeleri şu şekildedir; katılımcı mizah: $\left(1^{*}, 5,9^{*}, 13\right.$, $\left.17^{*}, 21,25^{*}, 29^{*}\right)$, kendini geliştirici mizah: $\left(2,6,10,14,18,22^{*}, 26,30\right)$, saldırgan mizah: $\left(3,7^{*}, 11,15^{*}, 19,23^{*}\right.$, $\left.27,31^{*}\right)$ ve kendini yıkıcı mizah: $\left(4,8,12,16^{*}, 20,24,28,32\right)$. (*ile işaretlenen maddeler ters yönde puanlanmaktadır).

Hipotez, araştırmayı sonuca ulaştıran önemli bir pusula olmakla birlikte araştırılan konuyla alakalı olarak ileri sürülen yanlışlığı ve doğruluğu hala denenmemiş olan bir ifade olarak belirtilmektedir (Yüksel ve Yüksel, 2004: 36). Başka bir tanıma göre ise değişkenler veya olaylar arasında var olduğu belirtilen ilişki olarak ifade edilmektedir (Karasar, 2013: 68). Yapılan literatür incelemesi sonucunda stresle başa çıkma tarzları ve mizah tarzları arasında ilişki olduğu tespit edilmiştir. Bu doğrultuda, Abel (2002), Yerlikaya (2007) ve Özdemir ve diğerleri (2011) tarafindan yapılan araştırmaların sonuçları dikkate alınarak, bu araştırmanın hipotezleri şu şekilde belirlenmiştir:

$$
\begin{aligned}
& H_{1}=\text { "Turist rehberlerinin kendine güvenli yaklaşımları, stresle başa çıkma tarzlarını etkilemektedir." } \\
& H_{2}=\text { "Turist rehberlerinin çaresiz yaklaşımları, stresle başa çıkma tarzlarını etkilemektedir." } \\
& H_{3}=\text { "Turist rehberlerinin boyun eğici yaklaşımları, stresle başa çıkma tarzlarını etkilemektedir." } \\
& H_{4}=\text { "Turist rehberlerinin iyimser yaklaşımları, stresle başa çıkma tarzlarını etkilemektedir." } \\
& H_{5}=\text { "Turist rehberlerinin sosyal destek arama durumları, stresle başa çıkma tarzlarını etkilemektedir." } \\
& H_{6}=\text { "Turist rehberlerinin katılımcı mizahları, mizah tarzlarını etkilemektedir." } \\
& H_{7}=\text { "Turist rehberlerinin kendini geliştirici mizahlarl, mizah tarzlarını etkilemektedir." } \\
& H_{8}=\text { "Turist rehberlerinin saldırgan mizahları, mizah tarzlarını etkilemektedir." } \\
& H_{9}=\text { "Turist rehberlerinin kendini yıkıcı mizahları, mizah tarzlarını etkilemektedir." } \\
& H_{10}=\text { "Turist rehberlerinin stresle başa çıkma tarzları, mizah tarzlarını etkilemektedir." } \\
& H_{11}=\text { "Turist rehberlerinin mizah tarzlarl, stresle başa çıkma tarzlarını etkilemektedir." }
\end{aligned}
$$

Araştırma kapsamında katılımcıların anket formundaki sorulara vermiş oldukları yanıtların analizinde SPSS 21.0 programından yararlanılmıştır. Araştırmada ilk olarak katılımcı turist rehberlerinin sosyo-demografik özelliklerine yönelik frekans analizi, daha sonra stresle başa çıkma tarzları ve mizah tarzları ölçeğine yönelik faktör analizi ve güvenirlik analizi yapılmıştır. Ölçeklerin faktör analizi sonucunda belirlenen faktörlerinin aritmetik ortalama ve standart sapma değerleri hesaplanmıştır. Ayrıca araştırmada ölçekler ve faktörler arasındaki ilişki düzeylerini belirlemek amacıyla korelasyon analizi ve son olarak da hipotezlerin test edilmesi amacıyla regresyon analizi gerçekleştirilmiştir.

\section{Araştırmanın Bulguları}

Araştırmaya katılan turist rehberlerinin sosyo-demografik özelliklerine ilişkin frekans analizi sonuçları incelendiğinde katılımcıların büyük çoğunluğunun erkek olduğu gözlemlenmektedir. Bu doğrultuda araştırmaya katılan erkek turist rehberi oranının \%68,5 $(n=255)$ ve kadın turist rehberi oranının ise \%31,5 $(n=117)$ olduğu görülmektedir. Medeni duruma yönelik sonuçlara bakıldığında, evli katılımcıların \%52,7 (n=196) oranla çoğunluğu oluşturduğu saptanmıştır. Katılımcıların \%47,3 ( $\mathrm{n}=176)$ oranla ise bekâr oldukları tespit edilmiştir. Katılımcıların \%42,5'inin (n=158) 26-35 yaş arası turist rehberlerinden oluştuğu görülmektedir. Turist rehberlerinin yaş değişkenlerine ilişkin oranlar incelendiğinde, $36-45$ yaş $\% 31,5(n=117), 46-55$ yaş $\% 12,2(n=45), 18-25$ yaş $\% 11(n=41), 56-65$ yaş $\% 2,4(n=9)$ ve 65 yaş ve üzeri ise $\% 0,5(\mathrm{n}=2)$ oranındadır. Katılımcıların öğrenim durumlarına bakıldığında ise $\% 56,7$ 'sinin $(\mathrm{n}=211)$ lisans düzeyinde, \%26,1'inin ( $n=97)$ lisansüstü düzeyinde, \%14'ünün $(n=52)$ ön lisans düzeyinde ve \%3,2'sinin (n=12) lise düzeyinde eğitim derecelerine sahip oldukları görülmektedir. Katılımcıların mesleki rehberlik eğitimlerini \%43,3 (n=161) oranıyla Kültür ve Turizm Bakanlığı sertifika programlarından, \%35,5 (n=132) oranıyla turist/turizm rehberliği lisans programlarından ve son olarak da \%21,2 (n=79) oranıyla turist/turizm rehberliği ön lisans programlarından aldıkları belirlenmiştir. Katılımcıların mesleği icra ettikleri yıla yönelik bulgulara bakıldığında, \%32,3'ünün (n=120) 5-9 y1l 
arası, \%30,1'inin (n=112) 15 y1l ve üzeri, \%16,9'unun (n=63) 10-14 y1l aras1, 14,8'inin (n=55) 1-4 y1l aras1 ve $\% 5,9$ 'unun $(\mathrm{n}=22)$ ise 1 yıldan daha az az süreye turist rehberliği mesleğini yerine getirdikleri saptanmıştır. Araştırmaya katılan turist rehberlerinin çoğunluğunun serbest çalıştı̆̆ $(\% 76,6 ; n=285)$ görülmektedir. Katılımcıların \%14'ünün $(n=52)$ sözleşmeli çalıştığı ve \%9,4'ünün $(n=35)$ ise kadrolu olarak çalıştığ saptanmıştır. Son olarak turist rehberlerinin mesleklerini icra ettikleri dillere bakıldığında ise \%72,6'sının ( $\mathrm{n}=270)$ İngilizce, \%7,8'inin ( $\mathrm{n}=29)$ Almanca, \%6,7'sinin $(\mathrm{n}=25)$ Fransizca, \%5,1'inin $(\mathrm{n}=19)$ Japonca, \%4'ünün $(\mathrm{n}=15)$ İtalyanca, \%2,2'sinin ( $\mathrm{n}=8)$ İspanyolca, \%1,9’unun (n=7) Çince ve \%1,1'inin (n=4) Portekizce dillerinde hizmet verdikleri görülmektedir.

Katılımcıların “meslek hayatınızın stresli olduğunu düşünüyor musunuz?” ve "mesleki hayatınızda yaşadı̆̆ınız stresi azaltmak için mizahı kullanıyor musunuz?" sorularına verdikleri cevaplara yönelik frekans analizi sonuçları bulunmaktadır. $\mathrm{Bu}$ doğrultuda turist rehberleri mesleki hayatlarının stresli olup olmadığına \%87,9 (n=327) oranıyla evet, \%12,1 ( $\mathrm{n}=45)$ oranıyla ise hayır cevabını verdikleri görülmektedir. Mesleki hayattaki stresle başa çıkmada mizahı kullanıp kullanmama durumlarına verdikleri cevaplara bakıldığında ise \%83,9 $(n=312)$ oranıyla evet, \%16,1 (n=60) oranılla ise hayır dedikleri belirlenmiştir.

Tablo 1'de Stresle Başa Çıkma Tarzları Ölçeğine yönelik açıklayıcı faktör analizi ve güvenilirlik analizi sonuçları yer almaktadır. Yapılan analiz sonucunda faktör yükü 0,30'dan az olan "İçinde bulunduğum kötü durumu kimsenin bilmesini istemem” (Madde: 9), "Her şeyin istediğim gibi olmayacağına inanırım” (Madde: 19) ve "Sorunun gerçek nedenini anlayabilmek için başkalarına danışırım” (Madde: 29) ifadeleri analizden çıkarılmıştır. Bu maddeler ölçekten çıkarıldıktan sonra faktör analizi tekrar yapılmıştır. Analiz sonucunda, Kaiser-Meyer-Olkin örneklem ölçüm testi değeri 0,831 ve Bartlett değeri $\mathrm{p}=0,000<0,05$ sonuçları faktör analizinin uygulanabilir olduğunu göstermektedir. Analiz sonucunda ölçeğin 5 faktörle açıklandığı tespit edilmiştir. Bu faktörler orijinal ölçekte olduğu gibi adlandırılmıştır. Elde edilen faktörlere bakıldığında 7 madde ile ifade edilen "kendine güvenli yaklaşım” faktörünün tanımladığ fark \%21,149 ve güvenirlik katsayısı (Cronbach's Alpha) 0,76'dır. 8 madde ile ifade edilen "çaresiz yaklaşım” faktörünün tanımladığı fark \%12,188 ve güvenirlik katsayısı 0,76'dır. 5 madde ile ifade edilen "boyun eğici yaklaşım” faktörünün tanımladığ 1 fark \%5,784 ve güvenirlik katsayısı 0,60'dır. 5 madde ile ifade edilen "iyimser yaklaşım” faktörünün tanımladığ 1 fark \%5,355 ve güvenirlik katsayısı 0,71'dir. Son olarak 2 madde ile ifade edilen "sosyal destek arama" faktörünün tanımladığı fark \%4,744 ve güvenirlik katsayısı 0,70 olarak saptanmıştır. Bu doğrultuda toplam faktör fark1 $\% 49,220$ ve genel güvenirlik katsayısı ise 0,70 olarak belirlenmiştir. Bununla birlikte orijinalinde boyun eğici yaklaşım faktöründe yer alan “Olanlar karşısında kaderim buymuş derim” (Madde: 24) ifadesi yapılan analiz sonucunda çaresiz yaklaşım faktörü altında ortaya çıkmıştır.

Tablo 1 incelendiğinde, en yüksek ortalamanın 3,23 (\%80,75) ortalama ile “Kendine Güvenli Yaklaşım” faktörü olduğu görülmektedir. En yüksek ortalama değere sahip olan ikinci faktörün 3,10 $(\% 77,5)$ ortalama ile "Sosyal Destek Arama" faktörü olduğu ve üçüncü en yüksek ortalama değerine sahip faktörün 3,01 $(\% 75,25)$ ile "Iyimser Yaklaşım" faktörü olduğu görülmektedir. "Çaresiz Yaklaşım” faktörü 1,80 (\%45) ortalama ile dördüncü en yüksek ortalama değere sahip olan faktör olarak ortaya çıkmaktadır. "Boyun Ĕgici Yaklaşım” faktörü ise 1,73 (\%43,25) ortalama değeri ile son sırada yer almaktadır. Bununla birlikte, katılımcıların stresle başa çıkma düzeylerinin 2,57 (\%64,25) oranıyla ortalamanın üzerinde olduğu saptanmıştır.

Tablo 1. Stresle Başa Çıkma Tarzları Ölçeğine İlişkin Açıklayıcı Faktör Analizi Sonuçları

\begin{tabular}{|c|c|c|c|c|c|c|}
\hline & $\begin{array}{l}\text { Faktör } \\
\text { Yükü }\end{array}$ & $\begin{array}{c}\text { Öz } \\
\text { Değeri }\end{array}$ & $\begin{array}{l}\text { Açıklanan } \\
\text { Varyans }\end{array}$ & $\begin{array}{l}\text { Cronbach's } \\
\text { Alpha }\end{array}$ & $\bar{x}$ & SS \\
\hline \multicolumn{7}{|l|}{ KENDİNE GÜVENLİ YAKLAȘIM } \\
\hline Her şeye yeniden başlayacak gücü kendimde bulurum. & 0,709 & \multirow{7}{*}{5,710} & \multirow{7}{*}{$\% 21,149$} & \multirow{7}{*}{0,76} & \multirow{7}{*}{3,23} & \multirow{7}{*}{0,72} \\
\hline Hakkımı savunabileceğime inanırım. & 0,658 & & & & & \\
\hline $\begin{array}{l}\text { Mutlaka bir yol bulabileceğime inanır, bunun için } \\
\text { uğraşırım. }\end{array}$ & 0,652 & & & & & \\
\hline $\begin{array}{l}\text { Olayın/olayların değerlendirmesini yaparak en iyi } \\
\text { kararı vermeye çalışırım. }\end{array}$ & 0,627 & & & & & \\
\hline $\begin{array}{l}\text { Ne olursa olsun direnme ve mücadele etme gücünü } \\
\text { kendimde bulurum. }\end{array}$ & 0,614 & & & & & \\
\hline Problemi/Problemleri adım adım çözmeye çalıșırım. & 0,519 & & & & & \\
\hline $\begin{array}{l}\text { Bir kişi olarak iyi yönde değiştiğimi ve olgunlaştı̆̆ımı } \\
\text { hissederim. }\end{array}$ & 0,408 & & & & & \\
\hline \multicolumn{7}{|l|}{ ÇARESIZ YAKLAŞIM } \\
\hline "Benim suçum ne" diye düșünürüm. & 0,774 & \multirow{8}{*}{3,291} & \multirow{8}{*}{$\% 12,188$} & \multirow{8}{*}{0,76} & \multirow{8}{*}{1,80} & \multirow{8}{*}{0,70} \\
\hline Olanlar karșısında "kaderim buymuș" derim. & 0,704 & & & & & \\
\hline "Hep benim yüzümden oldu" diye düşünürüm. & 0,675 & & & & & \\
\hline Sorunun benden kaynaklandığını düşünürüm. & 0,670 & & & & & \\
\hline Bir mucize olmasını beklerim. & 0,499 & & & & & \\
\hline "Keşke daha güçlü olsaydım" diye düșünürüm. & 0,492 & & & & & \\
\hline Kendimi kapana sıkışmış gibi hissediyorum. & 0,332 & & & & & \\
\hline $\begin{array}{l}\text { Olayları kafama takıp, sürekli düşünmekten kendimi } \\
\text { alamam. }\end{array}$ & 0,290 & & & & & \\
\hline \multicolumn{7}{|l|}{ BOYUN EĞİCI YAKLAŞIM } \\
\hline Başa gelen çekilir diye düşünürüm. & 0,717 & \multirow{3}{*}{1,562} & \multirow{3}{*}{$\% 5,784$} & \multirow{3}{*}{0,60} & \multirow{3}{*}{1,73} & \multirow{3}{*}{0,75} \\
\hline Problemin çözümü için adak adarım. & 0,596 & & & & & \\
\hline Mücadeleden vazgeçerim. & 0,582 & & & & & \\
\hline
\end{tabular}




\begin{tabular}{|c|c|c|c|c|c|c|}
\hline İș olacağına varır diye düşünürüm. & 0,560 & & & & & \\
\hline Elimden hiçbir şeyin gelmeyeceğine inanırım. & 0,666 & & & & & \\
\hline IYYIMSER YAKLAŞIM & & & & & & \\
\hline $\begin{array}{l}\text { Olaydan/olaylardan olumlu bir şey çıkarmaya } \\
\text { çalışırım. }\end{array}$ & 0,651 & \multirow{5}{*}{1,446} & \multirow{5}{*}{$\% 5,355$} & \multirow{5}{*}{0,71} & \multirow{5}{*}{3,01} & \multirow{5}{*}{0,77} \\
\hline İyimser olmaya çalışırım. & 0,541 & & & & & \\
\hline Olayları büyütmeyip üzerinde durmamaya çalışırım. & 0,493 & & & & & \\
\hline Kendime karşı hoşgörülü olmaya çalışırım. & 0,456 & & & & & \\
\hline Sakin kafayla düşünmeye, öfkelenmemeye çalışırım. & 0,441 & & & & & \\
\hline \multicolumn{7}{|l|}{ SOSYAL DESTEK ARAMA } \\
\hline *Kimsenin bilmesini istemem. & 0,523 & \multirow[b]{2}{*}{1,281} & \multirow[b]{2}{*}{$\% 4,744$} & \multirow[b]{2}{*}{0,70} & \multirow[b]{2}{*}{3,10} & \multirow[b]{2}{*}{0,70} \\
\hline $\begin{array}{l}\text { Bana destek olabilecek kişilerin varlığını bilmek beni } \\
\text { rahatlatır. }\end{array}$ & 0,474 & & & & & \\
\hline AÇIKLANAN VARYANS & \multicolumn{6}{|c|}{49,220} \\
\hline KAISER-MEYER-OLKIN (KMO) & \multicolumn{6}{|c|}{0,831} \\
\hline BARTLETT TESTİ & \multicolumn{6}{|c|}{$\mathrm{p}<0,000$} \\
\hline CRONBACH'S ALPHA & \multicolumn{6}{|c|}{0,70} \\
\hline
\end{tabular}

Tablo 2'de Mizah Tarzları Ölçeğine yönelik açıklayıcı faktör analizi sonucunda faktör yükü 0,30'dan az olan "Başımdan geçen komik şeyleri anlatarak insanları pek güldürmem” (Madde: 9), "Çoğunlukla kendi kendimi kötüleyen ya da alaya alan espriler yapmam” (Madde: 16), "Espriler yaparken ya da komik olmaya çalışırken çoğunlukla kendimi gereğinden fazla eleştiririm" (Madde: 20), "Kederli ya da üzgünsem genellikle mizahi bakış açımı kaybederim" (Madde: 22) ve "Sorunlarım varsa ya da üzgünsem, çoğunlukla gerçek duygularımı, en yakın arkadaşlarım bile anlamasın diye, espriler yaparak gizlerim” (Madde: 28) ifadeleri analizden çıkarılmış ve ölçeğe ait faktör analizi tekrarlanmıştır. Elde edilen Kaiser-Meyer-Olkin örneklem ölçüm testi değeri 0,760 ve Bartlett değeri $\mathrm{p}=0,000<0,05$ sonuçları, faktör analizinin uygulanabilir olduğunu göstermektedir. Analiz sonucunda ölçeğin 4 faktör ile açıklandığı tespit edilmiş ve faktörler orijinal ölçekte olduğu gibi adlandırılmıştır. Elde edilen faktörlere bakıldığında 8 madde ile ifade edilen "katılımc mizah" faktörünün tanımladığı fark \%17,386 ve güvenirlik katsayıSı (Cronbach's Alpha) 0,75 olarak belirlenmiştir. 6 madde ile ifade edilen "kendini geliştirici mizah" faktörünün tanımladı̆̆ 1 fark $\% 11,843$ ve güvenirlik katsayısı 0,76'dır. 8 madde ile ifade edilen "saldırgan mizah" faktörünün tanımladığı fark $\% 7,518$ ve güvenirlik katsayısı ise 0,65 şeklindedir. Son olarak 5 madde ile ifade edilen "kendini yıkıcı mizah" faktörünün tanımladığı fark ise \%5,922 ve güvenirlik katsayısı 0,66 olarak saptanmıştır. Bu doğrultuda toplam faktör fark1 \%42,669 ve genel güvenirlik katsayısı dağılımı ise 0,75 olarak belirlenmiştir. Bununla birlikte orijinalinde kendini geliştirici mizah faktöründe yer alan "Moralim bozuk olduğunda genellikle kendimi mizahla neşelendirebilirim" (Madde: 2) ifadesi yapılan analiz sonucunda katılımcı mizah faktörünün altında yer aldığı görülmektedir. Tablo 2 incelendiğinde, Mizah Tarzları Ölçeği faktörleri arasında en yüksek ortalamaya sahip olan faktör, 5,32 ortalama ile "Katılımcı Mizah" faktörüdür. En yüksek ortalama değere sahip olan ikinci mizah tarzları faktörü ise 4,64 ortalama ile "Kendini Geliştirici Mizah" ve üçüncü en yüksek ortalama değere sahip olan faktörün 3,25 ile "Kendini Yıkıcı Mizah" faktörü olduğu belirlenmiştir. "Saldırgan Mizah" faktörü ise 2,48 ortalama değeri ile dördüncü sırada yer almaktadır. Rehberlerin genel mizah tarzları seviyelerinin 3,92'lik bir değer ile orta düzeyde olduğu tespit edilmiştir.

Tablo 2. Mizah Tarzları Ölçeğine İlişkin Açıklayııı Faktör Analizi Sonuçları

\begin{tabular}{|c|c|c|c|c|c|c|}
\hline & $\begin{array}{l}\text { Faktör } \\
\text { Yükü }\end{array}$ & $\begin{array}{c}\text { Öz } \\
\text { Değeri }\end{array}$ & $\begin{array}{l}\text { Açılklanan } \\
\text { Varyans }\end{array}$ & $\begin{array}{l}\text { Cronbach's } \\
\text { Alpha }\end{array}$ & $\bar{x}$ & $S S$ \\
\hline \multicolumn{7}{|l|}{ KATILIMCI MIZAH } \\
\hline *Arkadaşlarımla çok sık şakalaşmam. & 0,704 & \multirow{8}{*}{4,694} & \multirow{8}{*}{$\% 17,386$} & \multirow{8}{*}{0,75} & \multirow{8}{*}{5,32} & \multirow{8}{*}{1,70} \\
\hline $\begin{array}{l}\text { *Genellikle fikra anlatmaktan ve insanları eğlendirmekten } \\
\text { hoşlanmam. }\end{array}$ & 0,612 & & & & & \\
\hline $\begin{array}{l}\text { *Genellikle çok fazla gülmem ya da başkalarıyla } \\
\text { şakalaşmam. }\end{array}$ & 0,599 & & & & & \\
\hline $\begin{array}{l}\text { *Başkalarıla birlikteyken genellikle aklıma söyleyecek } \\
\text { esprili şeyler gelmez. }\end{array}$ & 0,591 & & & & & \\
\hline $\begin{array}{l}\text { Moralim bozuk olduğunda genellikle kendimi mizahla } \\
\text { neşelendirebilirim. }\end{array}$ & 0,573 & & & & & \\
\hline Yakın arkadaşlarımla çok sık şakalaşır ve gülerim. & 0,505 & & & & & \\
\hline $\begin{array}{l}\text { İnsanları güldürmek için çok fazla uğraşmam gerekmez- } \\
\text { doğuştan esprili bir insan gibiyimdir. }\end{array}$ & 0,476 & & & & & \\
\hline İnsanları güldürmekten hoşlanırım. & 0,460 & & & & & \\
\hline \multicolumn{7}{|l|}{ KENDİNI GELIŞTİRICİ MİZAH } \\
\hline $\begin{array}{l}\text { Üzgün ya da mutsuzsam, kendimi daha iyi hissetmek için } \\
\text { genellikle o durumla ilgili gülünç bir şeyler düşünmeye } \\
\text { çalışırım. }\end{array}$ & 0,765 & \multirow{4}{*}{3,198} & \multirow{4}{*}{$\% 11,843$} & \multirow{4}{*}{0,76} & \multirow{4}{*}{4,64} & \multirow{4}{*}{1,85} \\
\hline $\begin{array}{l}\text { Tek başınaysam ve mutsuzsam, kendimi neşelendirecek } \\
\text { gülünç şeyler düşünmeye çalışırım. }\end{array}$ & 0,701 & & & & & \\
\hline $\begin{array}{l}\text { Tecrübelerime göre bir durumun eğlendirici yanlarını } \\
\text { düşünmek, sorunlarla başa çıkmada çoğunlukla etkili bir } \\
\text { yoldur. }\end{array}$ & 0,677 & & & & & \\
\hline $\begin{array}{l}\text { Yaşama karşı takındığım mizahi bakış açısı, benim olaylar } \\
\text { karşısında aşırı derecede üzülmemi ya da kederlenmemi }\end{array}$ & 0,531 & & & & & \\
\hline
\end{tabular}




\begin{tabular}{|c|c|c|c|c|c|c|}
\hline \multicolumn{2}{|l|}{ önler. } & & & & & \\
\hline $\begin{array}{l}\text { Neşelenmek için başkalarıyla birlikte olmam gerekmez, } \\
\text { genellikle tek başımayken bile gülecek şeyler bulabilirim. }\end{array}$ & 0,525 & & & & & \\
\hline $\begin{array}{l}\text { Tek başıma bile olsam çoğunlukla yaşamın gariplikleriyle } \\
\text { eğlenirim. }\end{array}$ & 0,437 & & & & & \\
\hline \multicolumn{7}{|l|}{ SALDIRGAN MIZAH } \\
\hline $\begin{array}{l}\text { *Bir şey bana gerçekten gülünç gelse bile, birini } \\
\text { gücendirecekse eğer, buna gülmem ya da bununla ilgili espri } \\
\text { yapmam. }\end{array}$ & 0,694 & \multirow{8}{*}{2,030} & \multirow{8}{*}{$\% 7,518$} & \multirow{8}{*}{0,65} & \multirow{8}{*}{2,48} & \multirow{8}{*}{1,7} \\
\hline $\begin{array}{l}\text { Bazen öyle komik şeyler gelir ki aklıma bunlar insanları } \\
\text { incitebilecek, yakışı almaz şeyler olsa bile, kendimi } \\
\text { tutamam söylerim. }\end{array}$ & 0,580 & & & & & \\
\hline $\begin{array}{l}\text { Espri yaparken ya da komik bir şey söylerken genellikle } \\
\text { karşımdakilerin bunu nasıl kaldıracağını pek önemsemem. }\end{array}$ & 0,576 & & & & & \\
\hline $\begin{array}{l}\text { Birinden hoşlanmazsam çoğunlukla onu küçük düşürmek için } \\
\text { hakkında espri yapar ya da alay ederim. }\end{array}$ & 0,557 & & & & & \\
\hline $\begin{array}{l}\text { Birisi hata yaptığında çoğunlukla onunla bu konuda dalga } \\
\text { geçerim. }\end{array}$ & 0,547 & & & & & \\
\hline $\begin{array}{l}\text { *Bütün arkadaşlarım bunu yapıyor olsa bile, bir başkasıyla } \\
\text { alay edip ona gülerlerken asla onlara eşlik etmem. }\end{array}$ & 0,529 & & & & & \\
\hline $\begin{array}{l}\text { *Insanların, mizahı başkalarını eleştirmek ya da aşağılamak } \\
\text { için kullanmalarından hoşlanmam. }\end{array}$ & 0,409 & & & & & \\
\hline $\begin{array}{l}\text { İnsanlar asla benim mizah anlayışım yüzünden gücenmez ya } \\
\text { da incinmezler. }\end{array}$ & 0,281 & & & & & \\
\hline \multicolumn{7}{|l|}{ KENDİNI YIKICI MİZAH } \\
\hline $\begin{array}{l}\text { İnsanların benimle dalga geçmelerine ya da bana gülmelerine } \\
\text { gereğinden fazla izin veriyorum. }\end{array}$ & 0,698 & \multirow{5}{*}{1,599} & \multirow{5}{*}{$\% 5,922$} & \multirow{5}{*}{0,66} & \multirow{5}{*}{3,25} & \multirow{5}{*}{1,89} \\
\hline $\begin{array}{l}\text { Arkadaşlarımla ya da ailemle birlikteyken çoğunlukla, } \\
\text { hakkında espri yapılan ya da dalga geçilen kişi ben olurum. }\end{array}$ & 0,636 & & & & & \\
\hline $\begin{array}{l}\text { Kendimi yermem ailemi ya da arkadaşlarımı güldürüyorsa } \\
\text { eğer, çoğunlukla bu işi kendimden geçerek yaparım. }\end{array}$ & 0,551 & & & & & \\
\hline $\begin{array}{l}\text { Başkalarının bana gülmesine izin vermek; benim, ailemi ve } \\
\text { arkadaşlarımı neşelendirme tarzımdır. }\end{array}$ & 0,517 & & & & & \\
\hline $\begin{array}{l}\text { Çoğunlukla kendi güçsüzlüklerim, gaflarım ya da hatalarımla } \\
\text { ilgili gülünç şeylerden söz ederek, insanların beni daha çok } \\
\text { sevmesini ya da kabul etmesini sağlamaya çalışırım. }\end{array}$ & 0,469 & & & & & \\
\hline AÇIKLANAN VARYANS & \multicolumn{6}{|c|}{42,669} \\
\hline KAISER-MEYER-OLKIN (KMO) & \multicolumn{6}{|c|}{0,760} \\
\hline BARTLETT TESTI & \multicolumn{6}{|c|}{$\mathrm{p}<0,000$} \\
\hline CRONBACH'S ALPHA & \multicolumn{6}{|c|}{0,75} \\
\hline
\end{tabular}

Tablo 3'te turist rehberlerinin stresle başa çıkma tarzları ile mizah tarzları arasındaki ilişkinin ortaya çıkarılması amacıyla yapılan korelasyon analizi sonuçları yer almaktadır. Analiz sonuçlarına göre turist rehberlerinin kendine güvenli yaklaşımları ile katılımcı mizah tarzları $(\mathrm{r}=0,295 ; \mathrm{p}=0,00<0,01)$ ve kendini geliştirici mizah tarzları $(\mathrm{r}=0,246 ; \mathrm{p}=0,00<0,01)$ ile düşük seviyede olumlu yönde anlamlı bir ilişkisi olduğu, saldırgan mizah tarzları $(\mathrm{r}=0,202$; $\mathrm{p}=0,00<0,01)$ ve kendini yıkıcı mizah tarzları $(r=-1,57 ; \mathrm{p}=0,00<0,01)$ ile de olumsuz yönlü anlamlı bir ilişkisi olduğu görülmektedir. Çaresiz yaklaşım faktörü ile saldırgan mizah $(\mathrm{r}=0,192 ; \mathrm{p}=0,00<0,01)$ ve kendini yıkıcı mizah $(\mathrm{r}=0,226$; $\mathrm{p}=0,00<0,01)$ arasında olumlu yönde anlamlı bir ilişki olduğu, katılımcı mizah $(r=0,295 ; p=0,00<0,01)$ ve kendini geliştirici mizah $(r=-0,217 ; \mathrm{p}=0,00<0,01)$ arasında ise olumsuz yönde anlamlı bir ilişki olduğu tespit edilmiştir. Turist rehberlerinin boyun eğici yaklaşımları ile kendini yıkıcı mizah tarzları arasında $(r=0,308 ; p=0,00<0,01)$ orta düzeyde olumlu yönde anlamlı bir ilişki bulunmakta; kendini geliştirici $(r=0,023 ; \mathrm{p}=0,00<0,01)$ ve saldırgan mizah $(\mathrm{r}=0,162$; $\mathrm{p}=0,00<0,01)$ tarzları arasında ise düşük düzeyde olumlu yönde bir ilişki bulunmaktadır. Ayrıca katılımcıların boyun eğici yaklaşımları ile katılımcı mizah tarzları $(r=0,070 ; p=0,00<0,01)$ arasında düşük düzeyde olumsuz yönde ilişki bulunmaktadır. İyimser yaklaşım faktörü ile mizah tarzları ölçeği faktörleri incelendiğinde, iyimser yaklaşım ile kendini geliştirici mizah tarzları $(\mathrm{r}=0,423 ; \mathrm{p}=0,00<0,01)$ arasında orta seviyede olumlu yönde anlamlı bir ilişki olduğu görülmektedir. Bunun yanı sıra iyimser yaklaşım ile katılımcı mizah $(\mathrm{r}=0,267 ; \mathrm{p}=0,00<0,01)$ ve kendini yıkıcı mizah arasında $(\mathrm{r}=0,028 ; \mathrm{p}=0,00<0,01)$ düşük seviyede olumlu yönde ilişki bulunmakta, ayrıca saldırgan mizah $(\mathrm{r}=-0,170$; $\mathrm{p}=0,00<0,01)$ ile de olumsuz yönde düşük seviyede bir ilişki bulunmaktadır. Sosyal destek arama ile katılımcı mizah $(\mathrm{r}=0,106 ; \mathrm{p}=0,00<0,01)$, kendini geliştirici mizah $(\mathrm{r}=0,219 ; \mathrm{p}=0,00<0,01)$ ve kendini yıkıc1 mizah $(\mathrm{r}=0,027$; $\mathrm{p}=0,00<0,01)$ tarzları arasında düşük seviyede olumlu yönde bir ilişki bulunurken, saldırgan mizah $(\mathrm{r}=0$-0,076; $\mathrm{p}=0,00<0,01)$ ile düşük seviyede olumsuz yönde bir ilişki içinde olduğu tespit edilmiştir. Analiz sonuçlarına göre olumlu mizah tarzlarının kullanımının stresle başa çıkmada olumsuz olan alt boyutları azalttığı, olumsuz mizah tarzlarının kullanımının ise stresle başa çıkmada olumlu olan alt boyutları azalttığı görülmektedir. 
Dumanlı, Ş., Köroğlu, Ö. / Journal of Yasar University, 2018, 13/52, 328-342

Tablo 3. Stresle Başa Çıkma Tarzları ile Mizah Tarzlarına İlişkin Korelasyon Analizi Sonuçları

\begin{tabular}{|c|c|c|c|c|c|c|}
\hline & & $\begin{array}{l}\text { Mizah } \\
\text { Tarzları }\end{array}$ & $\begin{array}{l}\text { Katılımc1 } \\
\text { Mizah }\end{array}$ & $\begin{array}{c}\text { Kendini } \\
\text { Geliştirici } \\
\text { Mizah } \\
\end{array}$ & $\begin{array}{l}\text { Saldırgan } \\
\text { Mizah }\end{array}$ & $\begin{array}{c}\text { Kendini } \\
\text { Yıkıcı Mizah }\end{array}$ \\
\hline \multirow{3}{*}{$\begin{array}{c}\text { Stresle Başa } \\
\text { Çıkma Tarzları }\end{array}$} & Korelasyon Katsayısı & $0,190 * *$ & 0,086 & $0,264 * *$ & $-0,51$ & $0,165 * *$ \\
\hline & Sig. & 0,000 & 0,096 & 0,000 & 0,330 & 0,001 \\
\hline & $\mathrm{N}$ & 372 & 372 & 372 & 372 & 372 \\
\hline \multirow{3}{*}{$\begin{array}{l}\text { Kendine } \\
\text { Güvenli } \\
\text { Yaklaşım }\end{array}$} & Korelasyon Katsayısı & $0,146 * *$ & $0,295 * *$ & $0,346 * *$ & $-0,202 * *$ & $-1,57 * *$ \\
\hline & Sig. & 0,005 & 0,000 & 0,000 & 0,000 & 0,002 \\
\hline & $\mathrm{N}$ & 372 & 372 & 372 & 372 & 372 \\
\hline \multirow{3}{*}{$\begin{array}{c}\text { Çaresiz } \\
\text { Yaklaşım }\end{array}$} & Korelasyon Katsayısı & $-0,096$ & $-0,295 * *$ & $-0,217 * *$ & $0,132 *$ & $0,226^{* *}$ \\
\hline & Sig. & 0,063 & 0,000 & 0,000 & 0,011 & 0,000 \\
\hline & $\mathrm{N}$ & 372 & 372 & 372 & 372 & 372 \\
\hline \multirow{3}{*}{$\begin{array}{l}\text { Boyun Eğici } \\
\text { Yaklaşım }\end{array}$} & Korelasyon Katsayısı & $0,154 * *$ & $-0,070$ & 0,023 & $0,162 * *$ & $0,308 * *$ \\
\hline & Sig. & 0,003 & 0,179 & 0,652 & 0,002 & 0,00 \\
\hline & $\mathrm{N}$ & 372 & 372 & 372 & 372 & 372 \\
\hline \multirow{3}{*}{$\begin{array}{l}\text { İyimser } \\
\text { Yaklaşım }\end{array}$} & Korelasyon Katsayısı & $0,245 * *$ & $0,267 * *$ & $0,423 * *$ & $-0,170 * *$ & 0,028 \\
\hline & Sig & 0,000 & 0,000 & 0,000 & 0,001 & 0,585 \\
\hline & $\mathrm{N}$ & 372 & 372 & 372 & 372 & 372 \\
\hline \multirow{3}{*}{$\begin{array}{c}\text { Sosyal Destek } \\
\text { Arama }\end{array}$} & Korelasyon Katsayısı & $0,120 * *$ & $0,106^{*}$ & $0,219 * *$ & $-0,76$ & 0,027 \\
\hline & Sig. & 0,020 & 0,000 & 0,000 & 0,142 & 0,610 \\
\hline & $\mathrm{N}$ & 372 & 372 & 372 & 372 & 372 \\
\hline
\end{tabular}

Araştırmanın hipotezlerinin test edilmesi amacıyla basit doğrusal regresyon analizleri yapılmıştır. Tablo 4 'te yer alan regresyon analizi sonuçları, $\mathrm{H}_{1}$ 'in $\mathrm{F}$ değerinin $(195,015) \mathrm{p}=0,000$ düzeyinde anlamlılık ifade ettiğini göstermektedir. Kendine güvenli yaklaşım faktörü, stresle başa çıkma tarzlarındaki değişimi \%34,5 $\left(\mathrm{R}^{2}=0,345\right)$ oranında açıklamaktadır. Regresyon katsayısı incelendiğinde $(B=0,315)$, kendine güvenli yaklaşım faktöründeki bir birimlik artışın stresle başa çıkma tarzları üzerinde olumlu yönde 0,315 'lik bir artışa sebep olacağı görülmektedir. Kendine güvenli yaklaşım, stresle başa çıkma tarzları üzerinde olumlu yönde anlamlı bir etkiye sahiptir ( $\mathrm{R}=0,587$; $t=13,965 ; \mathrm{p}=0,000<0,05$ ). Bu sonuca göre $\mathrm{H}_{1}$ (Turist rehberlerinin kendine güvenli yaklaşımlarl, stresle başa çıkma tarzlarını etkilemektedir) kabul edilmiştir. $\mathrm{H}_{2}$ 'in $\mathrm{F}$ değerinin $(77,910) \mathrm{p}=0,000$ düzeyinde anlamlılık ifade ettiği görülmektedir. Çaresiz yaklaşım faktörü, stresle başa çıkma tarzlarındaki değişimi \%17,4 $\left(\mathrm{R}^{2=} 0,174\right)$ oranında açıklamaktadır. Regresyon katsayısı incelendiğinde $(B=0,239)$, çaresiz yaklaşım faktöründeki bir birimlik artışın stresle başa çıkma tarzları üzerinde olumlu yönde $0,239^{\prime}$ luk bir artışa sebep olacağı görülmektedir. Çaresiz yaklaşım, stresle başa çıkma tarzları üzerinde olumlu yönde anlamlı bir etkiye sahiptir $(\mathrm{R}=0,417 ; \mathrm{t}=8,827 ; \mathrm{p}=0,000<0,05)$. $\mathrm{Bu}$ sonuç doğrultusunda $\mathrm{H}_{2}$ (Turist rehberlerinin çaresiz yaklaşımları, stresle başa çıkma tarzlarını etkilemektedir.) kabul edilmiştir. $\mathrm{H}_{3}$ 'in $\mathrm{F}$ değerinin (227,341) p=0,000 düzeyinde anlamlılık ifade ettiği görülmektedir. Boyun eğici yaklaşım faktörü, stresle başa çıkma tarzlarındaki değişimi $\% 38,1\left(\mathrm{R}^{2}=0,381\right)$ oranında açıklamaktadır. Regresyon katsayısı incelendiğinde $(B=0,325)$, boyun eğici yaklaşım faktöründeki bir birimlik artışın stresle başa çıkma tarzları üzerinde olumlu yönde $0,325^{\prime}$ lik bir artışa sebep olacağı görülmektedir. Boyun eğici yaklaşım, stresle başa çıkma tarzları üzerinde olumlu yönde anlamlı bir etkiye sahiptir $(\mathrm{R}=0,617 ; t=15,078 ; \mathrm{p}=0,000<0,05)$. Bu sonuç doğrultusunda $\mathrm{H}_{3}$ (Turist rehberlerinin boyun eğici yaklaşımları, stresle başa çıkma tarzlarını etkilemektedir.) kabul edilmiştir. $\mathrm{H}_{4}$ 'ün $\mathrm{F}$ değeri $(173,884) \mathrm{p}=0,000$ düzeyinde anlamlılık ifade etmektedir. İyimser yaklaşım faktörü, stresle başa çıkma tarzlarındaki değişimi \%32 $\left(\mathrm{R}^{2}=0,320\right)$ oranında açıklamaktadır. Regresyon katsayısı incelendiğinde $(\mathrm{B}=0,265)$, İyimser yaklaşım faktöründeki bir birimlik artışın stresle başa çıkma tarzları üzerinde olumlu yönde 0,265'lik bir artışa sebep olacağı görülmektedir. İyimser yaklaşım, stresle başa çıkma tarzları üzerinde olumlu yönde anlamlı bir etkiye sahiptir $(\mathrm{R}=0,565 ; t=13,186 ; \mathrm{p}=0,000<0,05)$. Bu sonuç doğrultusunda $\mathrm{H}_{4}$ (Turist rehberlerinin iyimser yaklaşımlarl, stresle başa çıkma tarzlarını etkilemektedir.) kabul edilmiştir. $\mathrm{H}_{5}$ 'in $\mathrm{F}$ değerinin $(67,253) \mathrm{p}=0,000$ düzeyinde anlamlılık ifade ettiği görülmektedir. Sosyal destek arama faktörü, stresle başa çıkma tarzlarındaki değişimi $\% 15,4\left(\mathrm{R}^{2}=0,154\right)$ oranında açıklamaktadır. Regresyon katsayısı incelendiğinde $(B=0,189)$, sosyal destek arama faktöründeki bir birimlik artışın stresle başa çıkma tarzları üzerinde olumlu yönde 0,189'luk bir artışa sebep olacağı görülmektedir. Sosyal destek arama faktörü, stresle başa çıkma tarzları üzerinde olumlu yönde anlamlı bir etkiye sahiptir $(\mathrm{R}=0,392 ; t=8,201 ; \mathrm{p}=0,000<0,05)$. $\mathrm{Bu}$ sonuç doğrultusunda $\mathrm{H}_{5}$ (Turist rehberlerinin sosyal destek arama durumları, stresle başa çıkma tarzlarını etkilemektedir.) kabul edilmiştir. 
Dumanlı, Ş., Köroğlu, Ö. / Journal of Yasar University, 2018, 13/52, 328-342

Tablo 4. Faktörlerin Stresle Başa Çıkma Tarzları Üzerindeki Etkisine İlişkin Regresyon Analizi Sonuçları

\begin{tabular}{|c|c|c|c|c|c|c|}
\hline & $\begin{array}{c}\text { Model } \\
\text { (Bağımsız Değișken) }\end{array}$ & $\begin{array}{c}\text { Standardize } \\
\text { Edilmemiş Katsayılar }\end{array}$ & $\begin{array}{l}\text { Standardize } \\
\text { Edilmiş }\end{array}$ & & & \\
\hline & Katsayılar & $\mathrm{B}$ & Standart Hata & Beta & $t$ Değeri & $\begin{array}{l}\text { Anlam } \\
\text { düzeyi }\end{array}$ \\
\hline \multirow{9}{*}{$\left(H_{l}\right)$} & Sabit & 1,461 & 0,074 & & 19,811 & 0,000 \\
\hline & Kendine Güvenli Yaklaşım & 0,315 & 0,023 & 0,587 & 13,965 & 0,000 \\
\hline & $\mathrm{R}$ & & & 0,587 & & \\
\hline & $\mathrm{R}^{2}$ & & & 0,345 & & \\
\hline & Düzeltilmiş $\mathrm{R}^{2}$ & & & 0,343 & & \\
\hline & Tahmini Standart Hata & & & 0,20173 & & \\
\hline & $\mathrm{F}$ & & & 195,015 & & \\
\hline & Anlam Düzeyi & & & 0,000 & & \\
\hline & Bă̆ımlı Değişken: Stresle B & Slkma Tarzları & & & & \\
\hline \multirow{9}{*}{$\left(H_{2}\right)$} & Sabit & 2,050 & 0,050 & & 40,910 & 0,000 \\
\hline & Çaresiz Yaklaşım & 0,239 & 0,027 & 0,417 & 8,827 & 0,000 \\
\hline & $\mathrm{R}$ & & & 0,417 & & \\
\hline & $\mathrm{R}^{2}$ & & & 0,174 & & \\
\hline & Düzeltilmiş $\mathrm{R}^{2}$ & & & 0,172 & & \\
\hline & Tahmini Standart Hata & & & 0,22657 & & \\
\hline & $\mathrm{F}$ & & & 77,910 & & \\
\hline & Anlam Düzeyi & & & 0,000 & & \\
\hline & Bağımlı Değişken: Stresle B & Ilkma Tarzları & & & & \\
\hline \multirow{9}{*}{$\left(H_{3}\right)$} & Sabit & 1,918 & 0,039 & & 49,642 & 0,000 \\
\hline & Boyun Eğici Yaklaşım & 0,325 & 0,022 & 0,617 & 15,078 & 0,000 \\
\hline & $\mathrm{R}$ & & & 0,617 & & \\
\hline & $\mathrm{R}^{2}$ & & & 0,381 & & \\
\hline & Düzeltilmiş $\mathrm{R}^{2}$ & & & 0,379 & & \\
\hline & Tahmini Standart Hata & & & 0,19620 & & \\
\hline & $\mathrm{F}$ & & & 227,341 & & \\
\hline & Anlam Düzeyi & & & 0,000 & & \\
\hline & Bağımlı Değişken: Stresle B & Ilkma Tarzları & & & & \\
\hline \multirow{9}{*}{$\left(H_{4}\right)$} & Sabit & 1,681 & 0,062 & & 27,314 & 0,000 \\
\hline & İyimser Yaklaşım & 0,265 & 0,020 & 0,565 & 13,186 & 0,000 \\
\hline & $\mathrm{R}$ & & & 0,565 & & \\
\hline & $\mathrm{R}^{2}$ & & & 0,320 & & \\
\hline & Düzeltilmiş $\mathrm{R}^{2}$ & & & 0,318 & & \\
\hline & Tahmini Standart Hata & & & 0,20561 & & \\
\hline & $\mathrm{F}$ & & & 173,884 & & \\
\hline & Anlam Düzeyi & & & 0,000 & & \\
\hline & Bağımlı Değişken: Stresle B & Slkma Tarzları & & & & \\
\hline \multirow{9}{*}{$\left(H_{5}\right)$} & Sabit & 1,892 & 0,073 & & 26,060 & 0,000 \\
\hline & Sosyal Destek Arama & 0,189 & 0,023 & 0,392 & 8,201 & 0,000 \\
\hline & $\mathrm{R}$ & & & 0,392 & & \\
\hline & $\mathrm{R}^{2}$ & & & 0,154 & & \\
\hline & Düzeltilmiş $\mathrm{R}^{2}$ & & & 0,152 & & \\
\hline & Tahmini Standart Hata & & & 0,22932 & & \\
\hline & $\mathrm{F}$ & & & 67,253 & & \\
\hline & Anlam Düzeyi & & & 0,000 & & \\
\hline & Bağımlı Değișken: Stresle B & Ikma Tarzlarl & & & & \\
\hline
\end{tabular}

Tablo 5'te görülen regresyon analizi sonuçları, $H_{6}$ 'nın $F$ değerinin $(263,121) \mathrm{p}=0,000$ düzeyinde anlamlılık ifade ettiğini belirtmektedir. Katılımcı mizah faktörü, mizah tarzlarındaki değişimi \%41,6 $\left(\mathrm{R}^{2}=0,416\right)$ oranında açıklamaktadır. Regresyon katsayısı incelendiğinde $(\mathrm{B}=0,407)$, katılımcı mizah faktöründeki bir birimlik artışın mizah tarzları üzerinde olumlu yönde 0,407'lik bir artışa sebep olacağı görülmektedir. Katılımcı mizah, mizah tarzları üzerinde olumlu yönde anlamlı bir etkiye sahiptir $(\mathrm{R}=0,645 ; t=16,221 ; \mathrm{p}=0,000<0,05) . \mathrm{Bu}$ sonuç doğrultusunda $\mathrm{H}_{6}$ (Turist rehberlerinin katılımcı mizahları, mizah tarzlarını etkilemektedir.) kabul edilmiştir. $\mathrm{H}_{7}$ 'nin $\mathrm{F}$ değeri $(349,477)$ $\mathrm{p}=0,000$ düzeyinde anlamlılık ifade etmektedir. Kendini geliştirici mizah faktörü, mizah tarzlarındaki değişimi \%48,6 $\left(\mathrm{R}^{2}=0,486\right)$ oranında açıklamaktadır. Regresyon katsayısı incelendiğinde $(\mathrm{B}=0,363)$, kendini geliştirici mizah faktöründeki bir birimlik artışın mizah tarzları üzerinde olumlu yönde 0,363'lük bir artışa sebep olacağı görülmektedir. Kendini geliştirici mizahın, mizah tarzları üzerinde olumlu yönde anlamlı bir etkiye sahip olduğu belirlenmiştir $(\mathrm{R}=0,697 ; t=18,694 ; \mathrm{p}=0,000<0,05)$. $\mathrm{Bu}$ sonuç doğrultusunda $\mathrm{H}_{7}$ (Turist rehberlerinin kendini geliştirici mizahlart, mizah tarzlarını etkilemektedir.) kabul edilmiştir. $\mathrm{H}_{8}$ 'in $\mathrm{F}$ değeri $(73,908) \mathrm{p}=0,000$ düzeyinde anlamlılı ifade etmektedir. Saldırgan mizah faktörü, mizah tarzlarındaki değişimi \%16,6 $\left(\mathrm{R}^{2}=0,166\right)$ oranında açıklamaktadır. Regresyon katsayısı incelendiğinde $(\mathrm{B}=0,288)$, saldırgan mizah faktöründeki bir birimlik artışın mizah tarzları üzerinde olumlu yönde $0,288^{\prime}$ lik bir artışa sebep olacağı görülmektedir. Saldırgan mizah, mizah tarzları üzerinde olumlu yönde anlamlı bir etkiye sahiptir $(\mathrm{R}=0,408 ; t=8,597 ; \mathrm{p}=0,000<0,05)$. Bu sonuç doğrultusunda $\mathrm{H}_{8}$ (Turist rehberlerinin 
saldırgan mizahları, mizah tarzlarını etkilemektedir.) kabul edilmiştir. $\mathrm{H}_{9}$ ’un F değeri $(271,877) \mathrm{p}=0,000$ düzeyinde anlamlılık ifade etmektedir. Kendini yıkıcı mizah faktörü, mizah tarzlarındaki değişimi $\% 42,4\left(\mathrm{R}^{2}=0,424\right)$ oranında açıklamaktadır. Regresyon katsayısı incelendiğinde $(B=0,344)$, kendini yıkıcı mizah faktöründeki bir birimlik artışın mizah tarzları üzerinde olumlu yönde 0,344'lük bir artışa sebep olacağı görülmektedir. Kendini yıkıcı mizah, mizah tarzları üzerinde olumlu yönde anlamlı bir etkiye sahiptir $(\mathrm{R}=0,651 ; t=16,489 ; \mathrm{p}=0,000<0,05)$. Bu sonuç doğrultusunda $\mathrm{H}_{9}$ (Turist rehberlerinin kendini yıkıcı mizahları, mizah tarzlarını etkilemektedir.) kabul edilmiştir.

Tablo 5. Faktörlerin Mizah Tarzları Üzerindeki Etkisine İlişkin Regresyon Analizi Sonuçları

\begin{tabular}{|c|c|c|c|c|c|c|}
\hline & $\begin{array}{c}\text { Model } \\
\text { (Bağımsız Değişken) }\end{array}$ & $\begin{array}{c}\text { Standardize } \\
\text { Edilmemiş Katsayılar }\end{array}$ & $\begin{array}{c}\text { Standardize } \\
\text { Edilmiş }\end{array}$ & & & \\
\hline & Katsayılar & B & Standart Hata & Beta & t Değeri & $\begin{array}{l}\text { Anlam } \\
\text { düzeyi }\end{array}$ \\
\hline \multirow{9}{*}{$\left(H_{6}\right)$} & Sabit & 1,781 & 0,136 & & 13,090 & 0,000 \\
\hline & Katılımcı Mizah & 0,407 & 0,025 & 0,645 & 16,221 & 0,000 \\
\hline & $\mathrm{R}$ & & & 0,645 & & \\
\hline & $\mathrm{R}^{2}$ & & & 0,416 & & \\
\hline & Düzeltilmiş $\mathrm{R}^{2}$ & & & 0,414 & & \\
\hline & Tahmini Standart Hata & & & 0,49932 & & \\
\hline & $\mathrm{F}$ & & & 263,121 & & \\
\hline & Anlam Düzeyi & & & 0,000 & & \\
\hline & Bağımlı Değişken: Mizah Tarzları & & & & & \\
\hline \multirow{9}{*}{$\left(H_{7}\right)$} & Sabit & 2,265 & 0,093 & & 24,292 & 0,000 \\
\hline & Kendini Geliştirici Mizah & 0,363 & 0,019 & 0,697 & 18,694 & 0,000 \\
\hline & $\mathrm{R}$ & & & 0,697 & & \\
\hline & $\mathrm{R}^{2}$ & & & 0,486 & & \\
\hline & Düzeltilmiş $\mathrm{R}^{2}$ & & & 0,484 & & \\
\hline & Tahmini Standart Hata & & & 0,46840 & & \\
\hline & $\mathrm{F}$ & & & 349,477 & & \\
\hline & Anlam Düzeyi & & & 0,000 & & \\
\hline & Bağımlı Değişken: Mizah Tarzları & & & & & \\
\hline \multirow{9}{*}{$\left(H_{8}\right)$} & Sabit & 3,234 & 0,089 & & 36,468 & 0,000 \\
\hline & Saldırgan Mizah & 0,288 & 0,033 & 0,408 & 8,597 & 0,000 \\
\hline & $\mathrm{R}$ & & & 0,408 & & \\
\hline & $\mathrm{R}^{2}$ & & & 0,166 & & \\
\hline & Düzeltilmiş $\mathrm{R}^{2}$ & & & 0,164 & & \\
\hline & Tahmini Standart Hata & & & 0,59632 & & \\
\hline & $\mathrm{F}$ & & & 73,908 & & \\
\hline & Anlam Düzeyi & & & 0,000 & & \\
\hline & Bağımlı Değişken: Mizah Tarzlart & & & & & \\
\hline \multirow{9}{*}{$\left(H_{9}\right)$} & Sabit & 2,830 & 0,073 & & 38,988 & 0,000 \\
\hline & Kendini Yıkıcı Mizah & 0,344 & 0,021 & 0,651 & 16,489 & 0,000 \\
\hline & $\mathrm{R}$ & & & 0,651 & & \\
\hline & $\mathrm{R}^{2}$ & & & 0,424 & & \\
\hline & Düzeltilmiş $\mathrm{R}^{2}$ & & & 0,422 & & \\
\hline & Tahmini Standart Hata & & & 0,49591 & & \\
\hline & $\mathrm{F}$ & & & 271,877 & & \\
\hline & Anlam Düzeyi & & & 0,000 & & \\
\hline & Bağımlı De ğişken: Mizah Tarzları & & & & & \\
\hline
\end{tabular}

Tablo 6'da stresle başa çıkma tarzlarının mizah tarzları üzerindeki etkisine ilişkin regresyon analizi sonuçları yer almaktadır. Tablo 6'ya göre $\mathrm{H}_{10}$ 'un $\mathrm{F}$ değeri $(13,833) \mathrm{p}=0,000$ düzeyinde anlamlılık ifade etmektedir. Stresle başa çıkma tarzları, mizah tarzlarındaki değişimi \%03,6 $\left(\mathrm{R}^{2}=0,036\right)$ oranında açıklamaktadır. Regresyon katsayısı incelendiğinde $(\mathrm{B}=0,497)$, stresle başa çıkma tarzlarındaki bir birimlik artışın mizah tarzları üzerinde olumlu yönde 0,497'lik bir artışa sebep olacağı görülmektedir. Stresle başa çıkma tarzları, mizah tarzları üzerinde olumlu yönde anlamlı bir etkiye sahiptir $(\mathrm{R}=0,190 ; t=3,719 ; \mathrm{p}=0,000<0,05)$. Bu sonuç doğrultusunda $\mathrm{H}_{10}$ (Turist rehberlerinin stresle başa çıkma tarzları, mizah tarzlarını etkilemektedir.) kabul edilmiştir.

Tablo 6. Stresle Başa Çıkma Tarzlarının Mizah Tarzları Üzerindeki Etkisine İlişkin Regresyon Analizi Sonuçları

\begin{tabular}{|c|c|c|c|c|c|c|}
\hline & $\begin{array}{c}\text { Model } \\
\text { (Bağımsız Değişken) }\end{array}$ & $\begin{array}{c}\text { Standardize } \\
\text { Edilmemiş Katsayılar }\end{array}$ & $\begin{array}{l}\text { Standardize } \\
\text { Edilmiş }\end{array}$ & & & \\
\hline & Katsayılar & 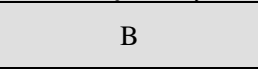 & Standart Hata & Beta & $t$ Değeri & $\begin{array}{l}\text { Anlam } \\
\text { düzeyi }\end{array}$ \\
\hline \multirow{5}{*}{$\left(H_{10}\right)$} & Sabit & 2,715 & 0,333 & & 8,147 & 0,000 \\
\hline & $\begin{array}{l}\text { Stresle Başa Çıkma } \\
\text { Tarzları }\end{array}$ & 0,497 & 0,134 & 0,190 & 3,719 & 0,000 \\
\hline & $\mathrm{R}$ & & & 0,190 & & \\
\hline & $\mathrm{R}^{2}$ & & & 0,036 & & \\
\hline & Düzeltilmiş $\mathrm{R}^{2}$ & & & 0,033 & & \\
\hline
\end{tabular}




\begin{tabular}{lc}
\hline Tahmini Standart Hata & 0,64129 \\
\cline { 2 - 2 } & 13,833 \\
\cline { 2 - 3 } Anlam Düzeyi & 0,000 \\
\hline Bağımlı Değissken: Mizah Tarzları & \\
\hline
\end{tabular}

Tablo 7'de mizah tarzlarının stresle başa çıkma tarzlarına etkisine ilişkin regresyon analizi sonuçları verilmektedir. Tablo 7'ye göre, $\mathrm{H}_{11}$ 'in $\mathrm{F}$ değeri $(13,833) \mathrm{p}=0,000$ düzeyinde anlamllık ifade etmektedir. Mizah tarzları, stresle başa çıkma tarzlarındaki değişimi $\% 0,36\left(\mathrm{R}^{2}=0,036\right)$ oranında açıklamaktadır. Regresyon katsayısı incelendiğinde $(\mathrm{B}=0,072)$, mizah tarzlarındaki bir birimlik artışın stresle başa çıkma tarzları üzerinde olumlu yönde 0,072 'lik bir artışa sebep olacağı görülmektedir. Mizah tarzları, stresle başa çıkma tarzlarının üzerinde olumlu yönde anlamlı bir ilişkiye sahip olduğu görülmektedir $(\mathrm{R}=0,190 ; t=3,719 ; \mathrm{p}=0,000<0,05)$. Bu sonuçlar doğrultusunda $\mathrm{H}_{11}$ (Turist rehberlerinin mizah tarzları, stresle başa çıkma tarzlarını etkilemektedir.) kabul edilmiştir.

Tablo 7. Mizah Tarzlarının Stresle Başa Çıkma Tarzlarına Etkisine İlişkin Regresyon Analizi Sonuçları

\begin{tabular}{|c|c|c|c|c|c|c|}
\hline & $\begin{array}{c}\text { Model } \\
\text { (Bağımsız Değişken) }\end{array}$ & $\begin{array}{c}\text { Standardize } \\
\text { Edilmemiş Katsayılar }\end{array}$ & $\begin{array}{c}\text { Standardize } \\
\text { Edilmiş }\end{array}$ & & & \\
\hline & Katsayılar & ( & Standart Hata & Beta & t Değeri & $\begin{array}{l}\text { Anlam } \\
\text { düzeyi }\end{array}$ \\
\hline \multirow{9}{*}{$\left(H_{11}\right)$} & Sabit & 2,194 & 0,078 & & 28,137 & 0,000 \\
\hline & Mizah Tarzları & 0,072 & 0,019 & 0,190 & 3,719 & 0,000 \\
\hline & $\mathrm{R}$ & & & 0,190 & & \\
\hline & $\mathrm{R}^{2}$ & & & 0,036 & & \\
\hline & Düzeltilmiş $\mathrm{R}^{2}$ & & & 0,033 & & \\
\hline & Tahmini Standart Hata & & & 0,24475 & & \\
\hline & $\mathrm{F}$ & & & 13,833 & & \\
\hline & Anlam Düzeyi & & & 0,000 & & \\
\hline & Bağımlı Değişken: Strest & a Çıkma Tarzları & & & & \\
\hline
\end{tabular}

\section{Sonuç ve Öneriler}

Araştırma sonucunda elde edilen bulgular arasında kullanılan ölçeklerin ortalamalarına yer verilmiştir. Stresle başa çıkma tarzları ölçeğinin genel ortalaması 2,57 (\%64,25) mizah tarzları ölçeğinin genel ortalaması ise 3,92 olarak ortaya çıkmaktadır. Turist rehberlerinin stresle başa çıkma düzeylerinin ortalamanın üzerinde olması, stresin hayatın her anında olması ve bir şekilde stresle başa çıkmayı başarmak zorunda olmaları ile bağdaştırılabilir. Mizah tarzlarının orta düzeyde olması ise Türkiye'de daha çok tarihi, arkeolojik, doğal güzelliklerinin anlatımının fazla olması ve bu anlatımlar sırasında turist rehberlerinin daha çok bilgi aktarımını esas alması ve turist rehberliği eğitim programlarında mizah kullanımına yönelik herhangi bir ders içeriğinin olmaması gibi sebeplerden kaynaklandığı düşünülmektedir.

Araştırma kapsamında stresle başa çıkma tarzları ölçeği faktörleri ve mizah tarzları ölçeği faktörlerinin birbirleri ile ilişkisinin ortaya çıkarılması adına yapılan korelasyon analizi sonuçlarına bakıldığında, stresle başa çıkma tarzlarından olumsuz olan çaresiz yaklaşım ve boyun eğici yaklaşım azaldıkça, mizah tarzlarından olumlu olan katılımcı mizah ve kendini geliştirici mizahın arttığı görülmektedir. Aynı şekilde olumsuz mizah tarzlarından saldırgan mizah ve kendini yıkıcı mizah tarzlarındaki artış ise stresle başa çıkmada olumlu olan kendine güvenli yaklaşım ve iyimser yaklaşımı azalttı̆̆ görülmektedir.

Araştırma sonucunda, katılımcıların stresle başa çıkma tarzları ile mizah tarzları arasında orta düzeyde anlamlı bir ilişki olduğu, mizah tarzları ile stresle başa çıkma tarzları arasında ise düşük düzeyde anlamlı bir ilişki olduğu saptanmıştır. Bu doğrultuda stresle başa çıkabilen turist rehberlerinin, başa çıkamayan turist rehberlerine göre mizah tarzlarını daha fazla kullandıkları görülmektedir. Stresle başa çıkma tarzlarını en çok etkileyen faktörün boyun eğici yaklaşım olduğu, mizah tarzlarını en çok etkileyen faktörün ise kendini geliştirici mizah faktörü olduğu saptanmıştır.

Bir turun başarılı geçip geçmemesinde turist rehberlerine önemli roller düşmektedir. Turist rehberlerinin anlatımlarını tekdüzelikten kaçınarak, eğlenceli ve ilgi çekici hale getirmelerinde mizahın önemli bir katkısı olduğu düşünülmektedir. Bu nedenle düzenlenen hizmet içi seminerlerinde turist rehberlerinin anlatım becerilerinin arttırılması ve anlatımları sırasında ses tonunu, jest ve mimiklerini daha etkili bir şekilde kullanabilmeleri açısından drama eğitimi gibi eğitim programlarına yer verilmelidir.

Turist rehberlerinin çalışma şartlarının zorlukları, kaçak rehberlere karşı verdikleri mücadele, işsiz kalma korkuları, herhangi bir lisans programından mezun olup bakanlığın açtığı sertifika programına katılarak yeterli donanıma sahip olamayan rehberlerin oluşturdukları tehditler, yasada belirtilen taban ücretlerini alamamaları, sektörde oluşan durgunluklar ve bunların yanı sıra kendi bireysel hayatlarındaki problemler ve aile yaşantılarındaki sorunlar gibi pek çok etkenin turist rehberlerinde strese neden olduğu düşünülmektedir. Bu strese neden olan durumların ilgili kuruluşlar tarafından rehberlerin sorunları dinlenerek tespit edilmesi önem taşımaktadır. Tespit edilen bu sorunların çözüme ulaştırılması adına adımların atılması da turist rehberlerinin ruhsal ve fiziksel sağlığı, turun başarılı geçmesi ve turdan duyulan memnuniyet düzeyinin arttırılması açısından önem taşıdığı düşünülmektedir.

Turist rehberlerinin mesleklerini icra ettikleri dillere bakıldığında İngilizce dilinde talebi aşan rehber sayısını olması, ancak ender dillerden ise sürekli rehbere ihtiyaç duyulması bu konudaki eksiklikleri ortaya koymaktadır. Bu 
doğrultuda eğitim kurumlarında nadir dillerin müfredata eklenmesi ve bu dillere hâkim rehberlerin yetiştirilmesi önem taşımaktadır. Aynı zamanda eğitim kurumlarındaki diğer ders içeriklerinin de gözden geçirilmesi, rehberlerin drama, tiyatro gibi alanlara yönelik eğitimleri de almaları mesleki hizmetin sunumunda olumlu bir etki oluşturacaktır. Verilen teorik eğitimlerin yanı sıra uygulamalı olarak gezilerin yapılması, turist rehberi adayı öğrencilerin meslek hayatına atılmadan önce tecrübe elde etmelerinin sağlanması önem taşımaktadır.

Turist rehberleri turizm olgusu içinde çok büyük önem taşımaktadırlar. Tur esnasında turistlerin ülkeyi nasıl tanıyacakları, gezip gördükleri yerlere yükledikleri anlamları, duydukları memnuniyet düzeyini ve daha pek çok faktörü turist rehberleri doğrudan etkilemektedir. Bu nedenle rehberlerin stresle başa çıkma durumları ve kullandıkları mizah tarzları önem taşımaktadır. Turist rehberliği mesleğinin stresli bir meslek olduğu aşikârdır. Ancak rehberlerin bu stresle başa çıkmak için kendilerine yöntemler geliştirmeleri ve stresi sağlıklı bir seviyeye indirerek meslek hayatlarında olumlu bir etki oluşturmaları önemlidir. Ayrıca turist rehberlerinin kullandıkları mizah tarzları da turun başarılı bir şekilde gerçekleşmesinde önemli rol oynamaktadır. Olumlu mizah tarzlarından olan katılımcı mizah ile kendini geliştirici mizah tarzlarına sahip rehberlerin daha başarılı bir tur gerçekleştirecekleri ve stresle başa çıkmada mizahı olumlu bir şekilde kullanabilecekleri düşünülmektedir. Bu nedenle turist rehberlerinin anlatımları zenginleştirmek ve turistleri sıkmadan keyifli zaman geçirmelerini sağlamak için kişisel gelişimlerini yerine getirmeleri, stresle başa çıkma yollarını bulmaları ve anlatımlarında olumlu mizah tarzlarından yararlanmalarının önemli olduğu bilinmelidir.

Turist rehberlerinin stresle başa çıkma tarzlarının belirlenmesi ve buna yönelik öneri ve programların geliştirilmesi önem taşımaktadır. Bu bağlamda gelecekte yapılacak olan çalışmalarda, turist rehberlerinin stresle başa çıkma tarzları, mizah tarzlarından farklı başka değişkenlerle ele alınarak bu konuda rehberlere yönelik stresle başa çıkma stratejileri belirlenebilir. Turizm sektörünün farklı alanlarında ve farklı değişkenlere yönelik stres ve mizahla ilgili çalışmalar yapılabilir. $\mathrm{Bu}$ araştırmadan hareketle, gelecekte yapılacak araştırmalarda turist rehberlerinin stresle başa çıkmada kullandıkları yöntemlere yönelik programlar oluşturulabilir. Rehberlerin mizahi anlatımlarını güçlendirmek adına çeşitli programlar ve eğitimler belirlenerek meslek kuruluşlarına öneri geliştirilebilir. 


\section{KAYNAKÇA}

Abel, M. H. (2002). "Humor, Stress and Coping Strategies". Humor: International Journal of Humor Research 15 (4): $365-381$.

Akyol, Ü. (2011). Ergenlerde İletişim Becerilerinin Yordayıcıları Olarak Öz-Duyarlık ve Mizah Tarzları. Yayınlanmamış Yüksek Lisans Tezi, Muğla Üniversitesi Eğitim Bilimleri Enstitüsü, Muğla.

Aldwin, C. M. (2007). Stres, Coping, and Development: An Integrative Perspective. New York: The Guilford Press.

Altunışık, R., Coşkun, R., Bayraktaroğlu, S. ve Yıldırım, E. (2012). Sosyal Bilimlerde Araştırma Yöntemleri SPSS Uygulamalı. (Geliştirilmiş 7. Baskı). İstanbul: Avcı Ofset.

Araştırma ve Eğitim Genel Müdürlüğü [AREGEM]. Web: http://aregem.kulturturizm.gov.tr/TR,178564/rehberlikistatistikleri.html adresinden 02.06.2018'de alınmıştır.

Aslan, Z. ve Çokal, Z. (2016). "Profesyonel Turist Rehberlerinin Kültürel Değerlere Katkısına İlişkin Turist Algıları". Journal of Tourism and Gastronomy Studies 4 (1): 53-69.

Batman, O., Yıldırgan, R. ve Demirtaş, N. (2000). Turizm Rehberliği. Adapazarı: Değişim Yayınları.

Bayram, G. E. ve Zengin, B. (2017). Turist Rehberlerinin Verimliliğinin Etkileyen Psikolojik Faktörler. Güzel, F., Özlem, Altıntaş, Volkan., ve Şahin, İlker. (Ed.), Turist Rehberliği Araştırmaları Öngörüler ve Uygulamalar (ss. 197-216). Ankara: Detay Yayıncilık.

Bilge, E. (2008). “Cem Yılmaz Anlatıları: Üstünlük Kuramı Bağlamında”. Türkbilig 16: 16-23.

Büyüköztürk, Ş., Çakmak, E. K., Akgün, Ö. E., Karadeniz, Ş. ve Demirel, F. (2016). Bilimsel Araştırma Yöntemleri. (21.Bask1). Ankara: Pegem Akademi.

Çelik, M. ve Atik, S. F. (2016). "Duygusal Emek Gösteriminin Çalışanlar Açısından Sonuçları: Seyahat Acentalarına Yönelik Bir Araştırma”. Akademik Sosyal Araştırmalar Dergisi 4 (36): 507-521.

Demirüstü, C., Binboğa, D., Öner, S. ve Özdamar, K. (2009). "Üniversite Öğrencilerinin Genel Sağlık Anketi Skorları ve Stresle Baş Etme Yöntemleri Arasındaki İlişki”. Türkiye Klinikleri Tıp Bilimleri Dergisi 29 (1): 6- 70.

Doğan, H., Üngüren, E. ve Kesgin, D. D. (2010). "Meslek ve Aile Yaşamı İlişkisi: Profesyonel Turist Rehberlerine Yönelik Bir Araştırma", Journal of Yasar University 20 (5): 3430-3442.

Erdem, Ç. (2015). Aile ve Sosyal Politikalar Bakanlığı İl Müdürlüğüne Müracaat Eden Eğitim Düzeyi ve Gelir Seviyesi Düşük Bireylerde Bağlanma Stillerinin Umutsuzluk Düzeyleri ve Stresle Başa Çıkma Tarzları Arasındaki İlişki. Yayınlanmamış Yüksek Lisans Tezi, İstanbul Arel Üniversitesi Sosyal Bilimler Enstitüsü, İstanbul.

Erözkan, A. (2009). "Üniversite Öğrencilerinin Kişiler Arası İlişki Tarzları ve Mizah Tarzları”. Dokuz Eylül Üniversitesi Buca Eğitim Fakültesi Dergisi 26: 56-66.

Freud, S. (1998). Espriler ve Bilinçdışı ile İlişkileri. 3. Basım. (Çev. Emre Kapkın). İstanbul: Payel Yayınevi.

Folkman, S. ve Lazarus, R. S. (1980). "An Analysis of Coping in a Middle-Aged Community Sample". Journal of Health and Social Behavior 21 (3): 219-239.

Güzel, F. Ö. (2007). Türkiye İmajının Geliştirilmesinde Profesyonel Turist Rehberlerinin Rolü (Alman Turistler Üzerine Bir Araştırma). Yayınlanmamış Yüksek Lisans Tezi, Balıkesir Üniversitesi Sosyal Bilimler Enstitüsü, Balıkesir.

Güzel, F. Ö. ve Köroğlu, Ö. (2014). "Turist Rehberlerinin Liderlik ve Aracılık Rollerinin Tur Deneyimine Etkisi: Doğa Turları Üzerine Bir Araştırma”. Gaziantep Üniversitesi Sosyal Bilimler Dergisi 13 (4): 939-960.

Hampes, W. P. (2006). "Humor and Shyness: The Relation Between Humor Styles and Shyness". Humor: International Journal of Humor Research 19 (2): 179-187.

Howard, J., Thwaites, R. ve Smith, B. (2001). "Investigating the Roles of the Indigenous Tour Guide". The Journal of Tourism Studies 12 (2): 32-39.

İşçen, P. (2006). Onkologların Çatışma Eğilimlerinin, Empatik Becerilerinin, İş Doyumlarının ve Stresle Başa Çıkma Tarzlarının İncelenmesi. Yayınlanmamış Yüksek Lisans Tezi, İstanbul Üniversitesi Sağlık Bilimleri Enstitüsü, İstanbul.

Karagöz, O. (2009). İlköğretim Türkçe Öğretmenlerinin Mizah Tarzları ile Tükenmişlik Düzeyleri Arasındaki İlişki. Yayınlanmamış Yüksek Lisans Tezi, Maltepe Üniversitesi Sosyal Bilimler Enstitüsü, İstanbul.

Karasar, N. (2013). Bilimsel Araştırma Yöntemi. (25.Basım). Ankara: Nobel Akademik Yayıncılık.

Köroğlu, Ö. (2009). İstanbul 2010 Avrupa Kültür Başkenti Uygulamaları Kapsamında Turist Rehberliği Eğitim Programlar1. 10. Ulusal Turizm Kongresi Bildiriler Kitab1 (21-24 Ekim 2009/Mersin), 1335-1345.

Martin, R. A. (2004). "Sense of Humor and Physical Health: Theoretical Issues, Recent Findings, and Future Directions". Humor: International Journal of Humor Research 17 (1/2): 1-19.

Martin, R. A., Kuiper, N. A., Olinger, J. L. ve Dance, K. A. (1993). "Humor, Coping With Stress, Self Concept, Psychological Well-Being”. International Journal of Humor Research 6 (1): 89-104.

Martin, R. A., Puhlik-Doris, P., Larsen, G., Gray, J. ve Weir, K. (2003). "Individual Differences of Uses of Humor and Their Relation to Psychological Well-Being: Development of the Humor Styles Questionnaire". Journal of Research in Personality 37 (1): 48-75.

Overholser, J. C. (1992). "Sense of Humour When Coping with Life Stress". Personality and Individual Differences 13: 799-804. 
Özdemir, S., Sezgin, F., Kaya, Z. ve Recepoğlu, E. (2011). “İlköğretim Okulu Öğretmenlerinin Stresle Başa Çıkma Tarzları ile Kullandıkları Mizah Tarzları Arasındaki İlişki”. Kuram ve Uygulamada Eğitim Yönetimi Dergisi 17 (3): 405-428.

Özer, G. (2014). Orta Öğretim Kurum Yöneticilerinin Mizah Tarzlarının İncelenmesi (Kayseri İli Örneği). Yayınlanmamış Yüksek Lisans Tezi, Erciyes Üniversitesi Eğitim Bilimleri Enstitüsü, Kayseri.

Patel, C. (1989). The Complete Guide to Stress Management. London: Vermillion Press.

Sarıkaya, P. (2007). Tükenmişlik Sendromunun Kişilik Özelliklerinden Denetim Odağı ile İlişkisi ve Bir Uygulama. Yayınlanmamış Yüksek Lisans Tezi, Marmara Üniversitesi Sosyal Bilimler Enstitüsü, İstanbul.

Schafer, W. (1987). Stress Management For Wellness. New York: Mc Graw Hill.

Selye, H. (1976). Stress without Distress. Serban, G. (Ed.), Psychopathology of Human Adaptation (pp. 137-146). Springer, Boston, MA.

Şahin, N. H. ve Durak A. (1995). “Stresle Başa Çıkma Tarzları Ölçeği: Üniversite Öğrencileri İçin Uyarlanması”. Türk Psikoloji Dergisi, 10 (34): 56-73.

Yamaç, Ö. (2009). Üniversite Öğrencilerinin Algıladıkları Sosyal Destek ile Stresle Başa Çıkma Stilleri Arasındaki İlişki. Yayınlanmamış Yüksek Lisans Tezi. Selçuk Üniversitesi Sosyal Bilimler Enstitüsü, Konya.

Yardımc1, İ. (2010). “Mizah Kavramı ve Sanattaki Yeri”. Uşak Üniversitesi Sosyal Bilimler Dergisi, 3 (2): 1-41.

Yerlikaya, E. E. (2003). Mizah Tarzları Ölçeği'nin (The Humor Styles Questionnaire) Uyarlama Çalışması. Yayınlanmamış Yüksek Lisans Tezi, Çukurova Üniversitesi Sosyal Bilimler Enstitüsü, Adana.

Yerlikaya, N. (2007). Lise Öğrencilerinin Mizah Tarzları ile Stresle Başa Çıkma Tarzları Arasındaki İlişkinin İncelenmesi. Yayınlanmamış Yüksek Lisans Tezi, Çukurova Üniversitesi Sosyal Bilimler Enstitüsü Eğitim Bilimleri Anabilim Dalı, Adana.

Yurtsever, H. (2009). Kişilik Özelliklerinin Stres Düzeyine Etkisi ve Stresle Başa Çıkma Yolları: Üniversite Öğrencileri Üzerine Bir Araştırma. Yayınlanmamış Yüksek Lisans Tezi. Dokuz Eylül Üniversitesi Sosyal Bilimler Enstitüsü, İzmir.

Yüksel, A. ve Yüksel. F. (2004). Turizmde Bilimsel Araştırma Yöntemleri. Ankara: Turhan Kitabevi Yayınları. 